\title{
Formation and age of sphalerite mineralization in carbonate rocks of Bajocian age in the Swiss Jura Mountains: evidence of Mesozoic hydrothermal activity
}

\author{
Natalia Efimenko $\cdot$ Jens Schneider • \\ Jorge E. Spangenberg $\cdot$ Massimo Chiaradia . \\ Thierry Adatte · Karl B. Föllmi
}

Received: 13 August 2013 / Accepted: 13 March 2014 / Published online: 27 March 2014

(C) Springer-Verlag Berlin Heidelberg 2014

\begin{abstract}
A combination of petrographic and geochemical techniques was applied to better constrain the origin and evolution of the fluid systems responsible for the formation of disseminated, Cd-rich (up to $0.6 \mathrm{wt} \%$ ), sphalerite $(\mathrm{ZnS})$ mineralization in the northeastern part of the Jura Mountains, Switzerland. The Rb-Sr ages of sphalerite samples indicate that a main phase of sphalerite formation occurred near the boundary between the late Middle and early Late Jurassic, at around $162 \mathrm{Ma}$. The negative $\delta^{34} \mathrm{~S}$ values ( -22.3 to $-5.3 \%$ ) suggest that biogenic sulfide sulfur was involved in $\mathrm{ZnS}$ precipitation. The strontium isotope composition is more radiogenic than that of contemporaneous seawater, reflecting the interaction of mineralizing fluids with silicate rocks. Lead isotope signatures are very uniform ${ }^{206} \mathrm{~Pb}^{\prime 204} \mathrm{~Pb}=18.63-18.67,{ }^{207} \mathrm{~Pb}{ }^{1204} \mathrm{~Pb}=15.63-$ $15.64,{ }^{208} \mathrm{~Pb}^{1204} \mathrm{~Pb}=38.51-38.63$ ), indicating an isotopically well-homogenized fluid system. The basement rocks underlying the Jurassic strata are considered to be the main source of metals for the sphalerite mineralization. The migration of deep-sourced hydrothermal saline
\end{abstract}

N. Efimenko · J. E. Spangenberg · T. Adatte · K. B. Föllmi $(\bowtie)$ Institut des Sciences de la Terre, Université de Lausanne, 1015 Lausanne, Switzerland

e-mail: karl.foellmi@unil.ch

J. Schneider

Departement of Earth and Environmental Sciences, K. U.

Leuven, Celestijnenlaan 200E, 3001 Heverlee, Belgium

J. Schneider

Department of Mineralogy, Technische Universität Bergakademie

Freiberg, Brennhausgasse 14, 09596 Freiburg, Germany

M. Chiaradia

Département de Minéralogie, Université de Genève,

1205 Geneva, Switzerland metal-bearing fluids into the Bajocian host carbonates containing sedimentary reduced sulfur resulted in the precipitation of sulfides. The period of sphalerite formation near the Middle-Late Jurassic boundary is characterized by enhanced tectonic and hydrothermal activity in Europe, related to the opening of the Central Atlantic and tectonic/ thermal subsidence during spreading of the Alpine Tethys. Our study provides evidence that the Bajocian carbonate rocks in the Jura Mountains area were affected by the circulation of deep-sourced metal-bearing hydrothermal fluids in response to these continent-wide tectonothermal events. The presence of sphalerite mineralization and associated geochemical anomalies in $\mathrm{Zn}$ and $\mathrm{Cd}$ contents in carbonate rocks may also be used to trace basement features.

Keywords Sphalerite $\cdot$ Cadmium $\cdot$ Jurassic $\cdot$ Limestone . Jura Mountains $\cdot \mathrm{Rb}-\mathrm{Sr}$ dating of sphalerite

\section{Introduction}

Abundant mineralizations in exposed basement rocks in the southern Black Forest region (SW Germany) indicate the influence of multiple phases of intensified hydrothermal activity related to the reactivation of basement structures during the Mesozoic and Cenozoic (Bonhomme et al. 1983; Pfaff et al. 2009; Romer et al. 2010; Brockamp et al. 2011). These hydrothermal episodes may have affected a larger area in Europe, but very little is known about its expression in the adjacent area of the northern and western Swiss Jura Mountains, directly to the south of the Black Forest crystalline massif (Fig. 1). Based on $\mathrm{K}-\mathrm{Ar}$ dating of clay minerals from Carboniferous to Triassic sediments in northern Switzerland, Schaltegger et al. (1995) concluded that Permo-Carboniferous sediments infilling graben structures 

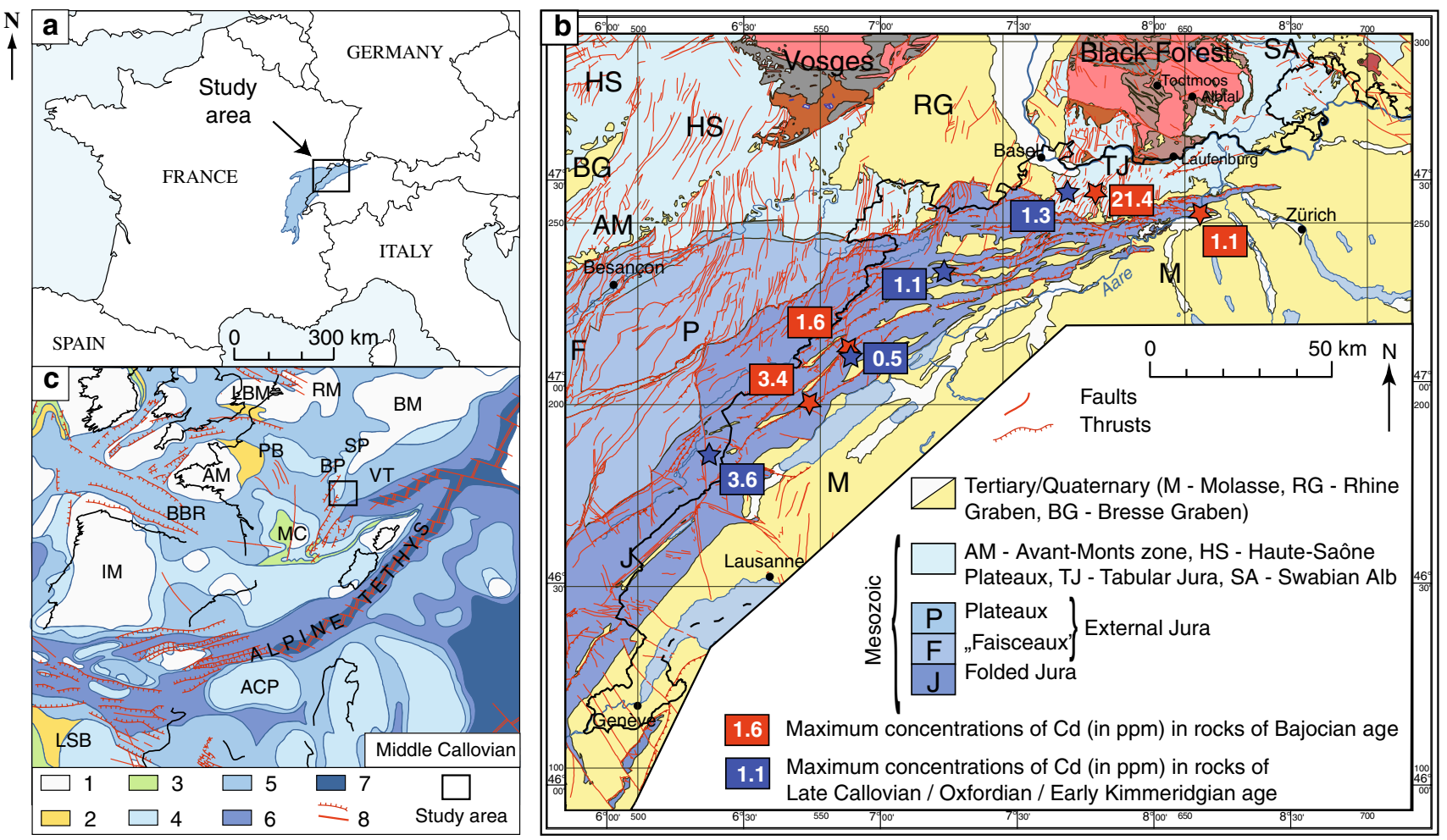

Fig. 1 Study area (modified from Jacquat et al. 2011). a Location of the Jura Mountains. b Regional tectonic map of the northeastern Jura Mountains, with maximal Cd concentrations measured in the rocks of Bajocian and Callovian-Kimmeridgian age (modified from the tectonic map of the Switzerland 2005; Cd concentrations are from Benitez-Vasquez 1999; Veuve 2000; Prudente 1999; Rambeau 2006). The grid (in $\mathrm{m}$ ) corresponds to the Swiss topographic coordinate system. c Paleogeographic position of the studied area during the middle Callovian (after Thierry and Barrier 2000). Depositional environments: 1 emerged areas (assumed and ascertained), 2 deltaic shallow marine (terrigenous), 3 shallow environments with fluctuating salinities, 4 shallow-marine carbonate deposits, 5 deep(er) carbonates (hemi) pelagic oozes, 6 deep marine, 7 deep oceanic basins. 6 Unspecified faults and normal faults. $A C P$ Apennine carbonate platform, $A M$ Armorican Massif, $B B R$ Bay of Biscay Rift, $B M$ Bohemian Massif, $B P$ Burgundy platform, $I M$ Iberian Massif, $M C$ Massif Central, $L B M$ London Brabant Massif, LSB Lower Sahara Basin, $P B$ Paris Basin, $R M$ Rhenish Massif, SP Swabian Platform, VT Valais Trough within the basement were affected by hydrothermal circulation during the Early Jurassic $(183 \pm 4 \mathrm{Ma})$, but that no evidence was found for younger (hydro)thermal events. According to the same authors, evidence of hydrothermal activity appeared also to be lacking in the Triassic sedimentary cover (Schaltegger et al. 1995).

Rare sulfide mineralizations are, however, present in the Triassic and Jurassic sedimentary cover of the Jura Mountains (Holenweg 1969; Hofmann 1989; Pearson et al. 1991; Hofmann and von Gehlen 1993). These mineralizations are often (but not always) dominated by sphalerite ( $\mathrm{ZnS}$; Fig. 2; Table 4), which occurs in the form of single, isolated crystals of up to $3 \mathrm{~cm}$ in diameter in primary and secondary porosities (Holenweg 1969; Holenweg and Offermann 1977; Hofmann 1989; Hofmann and von Gehlen 1993). Holenweg (1968), for example, identified and described the presence of sphalerite in fossil cavities within Jurassic carbonate rocks of the Swiss Jura Mountains (Table 4). He suggested that the mineralization was formed during early diagenesis and that organic matter was the most probable source of the metals. Furthermore, Hofmann (1989) studied base-metal sulfide mineralizations hosted in sedimentary rocks of Carboniferous to Cenozoic age in northern Switzerland and in southwestern Germany. He concluded that the $\mathrm{Pb}-\mathrm{Zn}$ mineralizations in carbonate rocks of Middle Triassic age (lower Muschelkalk formation) were formed by diagenetic remobilization of metals from associated marls, which were enriched in $\mathrm{Pb}, \mathrm{As}$ and $\mathrm{Zn}$ as a result of syngenetic processes (Hofmann and von Gehlen 1993; and references therein). In the aforementioned studies, the sulfide mineralization of the Swiss Jura Mountains was not specifically linked to hydrothermal activity and its exact age was never determined.

It was observed that sphalerite occurrences in oolitic carbonate formations of Bajocian and Oxfordian-Kimmeridgian in the Jura Mountains are spatially related to the occurrence of elevated Cd concentrations in limestone, of up to $21.4 \mathrm{mg} / \mathrm{kg}$, which is considerably higher than the mean concentration of $\mathrm{Cd}$ in limestone $-0.068 \mathrm{mg} / \mathrm{kg}$ (Fig. 1b; Gong et al. 1977; Heinrichs et al. 1980; Prudente 
Fig. 2 Regional geological map of the northeastern Jura Mountains (adapted from the geologic map of Switzerland 1:500,000, Swiss Federal Office of Topography, Berne, 1972) showing the position of sphalerite mineralization. Numbers indicated near the localities correspond to the numbers used in Table 5. SSGC Southern Schwarzwald Gneiss Complex



1999; Benitez-Vasquez 1999; Veuve 2000; Dubois et al. 2002; Rambeau 2006; Jacquat et al. 2009, 2011; QuezadaHinojosa et al. 2009; Rambeau et al. 2010). The high Cd (and $\mathrm{Zn}$ ) content in these carbonate formations was shown to be related to the presence of microscopic, isolated, Cdrich sphalerite crystals (Efimenko et al. 2008; Jacquat et al. 2009, 2011). At present, in the absence of extensive studies, the positive $\mathrm{Cd}$ and $\mathrm{Zn}$ anomalies is often the only indicator for the presence of sphalerite in Middle-Upper Jurassic carbonates in the Swiss Jura Mountains.

In the present study, we focus on the formation of sphalerite mineralization hosted by the carbonate rocks of the Bajocian and discuss its potential association with a hydrothermal pulse and fault (re)activation in the Jura Mountains. In particular, we seek to (1) discern the origin of sphalerite in carbonate rocks by tracing the source of sulfur and metals, and (2) constrain the timing of the hydrothermal pulse and fault (re)activation by dating the sphalerite. The approach used here includes thin-section microscopy, microprobe analyses, $\mathrm{Rb}-\mathrm{Sr}$ isotope dating, $\mathrm{Pb}-\mathrm{Pb}$ isotope tracing and strontium and sulfur isotope analyses of sphalerite samples collected in shallow-marine oolitic carbonates of Bajocian age.

Our results confirm earlier observations (e.g., Wetzel et al. 2003) that, whereas the faulting and thrusting associated with the formation of the Jura Mountains occurred during the late Miocene and Pliocene, part of the existing tectonic structures was formed much earlier and resulted from pre-orogenic phases related to the opening of the Atlantic Ocean during the Mesozoic, and possibly to west European rifting during the Oligocene (Homberg et al. 2002). Our study of the sphalerite mineralization suggests that the metals were transported by deep-sourced hydrothermal fluids, likely along deeply rooted faults, which cut through the sedimentary cover and the underlying top of the basement. Furthermore, the age of sphalerite formation near the Middle-Late Jurassic boundary helps to precise the timing of this phase of increased tectonic activity and fault (re)activation in the Jura Mountains.

\section{Geological setting and sulfide mineralization}

The Jura Mountains (Fig. 1a, b) is a young mountain chain corresponding to a basement high, which originated in the Oligocene between the Cenozoic basins of the Molasse Plateau to the south and southeast, the Rhine Graben to the north and the Bresse Graben to the west (Trümpy 1980). The sedimentary cover is composed of Mesozoic and Cenozoic rocks. These were detached from the underlying rocks 
along incompetent Triassic evaporite formations during the Mio-Pliocene and were translated $2-25 \mathrm{~km}$ into northern and northwestern directions thereby forming the fold-andthrust belt of the internal part of the Jura Mountains. The tectonic shortening is more pronounced along the southern part of the Folded Jura and decreases gradually toward the unfolded Tabular Jura in the northeast (Laubscher 1965). The Tabular Jura of northern Switzerland (Fig. 1b) is a part of the Meso-European cover of the Black Forest and Vosges basement uplift, affected by folding near the front to the Jura fold-and-thrust belt and by faulting (of essentially Oligocene age) in the vicinity of the Rhine Graben (Trümpy 1980). The study area is located in the northeastern part of the Jura, comprising both Folded and Tabular Jura units (Fig. 1b).

The crystalline basement underneath the Folded and Tabular Jura is the southern subsurface extension of the Black Forest crystalline massif (Peters 1987) and is composed of high-grade gneisses intruded by Variscan plutons, mainly granites and syenites (Kossmat 1927). During the final phase of the Variscan orogeny (Westphalian to Permian, around 315-245 Ma; Thury et al. 1994), ENEtrending graben structures were generated and filled by up to several kilometers thick Upper Carboniferous coal-rich sediments and Early Permian clastic sediments, which contain a large proportion of crystalline and/or volcanic components (Matter et al. 1988). Overlying sediments are composed of sandstone, anhydrite, gypsum, salt, dolomite, marl and carbonate of Triassic age, and marl and carbonate of Jurassic age. The thickness of Mesozoic strata in the study area is approximately $800 \mathrm{~m}$ (Thury et al. 1994). Sedimentation pattern during the Mesozoic were influenced by the multiple reactivation of Paleozoic basement structures, as is indicated indirectly by unconformities, erosional surfaces, lateral variations in lithofacies, and abrupt thickness changes (Pittet 1996; Gonzalez 1996; Quesne et al. 2000; Wetzel and Allia 2000, 2003; Allenbach 2002; Wetzel et al. 2003; Jank 2004; Ziegler et al. 2004; Allenbach and Wetzel 2006; Jank et al. 2006; Védrine and Strasser 2009). Direct evidence of tectonic activity in the Swiss Jura Mountains during the Mesozoic period is, however, missing, because of the lack of obvious synsedimentary tectonic features on the scale of seismic resolution (Allenbach 2002).

In the Jura Mountains, sulfide minerals other than pyrite are very rare and are found only in rocks older than Cretaceous in age. Sulfide assemblages in sedimentary rocks of Triassic age comprise sphalerite, pyrite, galena, and chalcopyrite associated with traces of bornite, digenite, minerals of the tennantite-tetrahedrite group and other sulfides. In Jurassic successions, the mineral paragenesis is simpler, with pyrite, marcasite and sphalerite being the most abundant sulfides (Table 4; Holenweg 1969; Graeser 1971; Hofmann 1989; Pearson et al. 1991; Hofmann and von Gehlen
1993). Other minerals occurring together with $\mathrm{Zn}$-sulfides in Mesozoic sedimentary rocks are barite, celestine, calcite, dolomite, ankerite, gypsum, goethite, and quartz (Table 4).

The sphalerite mineralization studied here occurs in oolitic carbonates of Middle-Late Bajocian age (Hauptrogenstein Formation; Gonzalez and Wetzel 1996) near Auenstein and Pratteln (Fig. 2). These carbonates accumulated in a shallow epicontinental sea in the southeastern portion of the Burgundy platform, which was part of the northern Tethyan margin. They occur west and north of the River Aare, in the Tabular and Folded Jura Mountains, and are replaced by the deeper-water, marl-dominated Klingnau Formation to the east (Gonzalez and Wetzel 1996). The thickness of the Hauptrogenstein Formation decreases from $130 \mathrm{~m}$ in the eastern Jura to $40-50 \mathrm{~m}$ in the west. More or less abrupt lateral changes in thickness and facies within the successions suggest local and regional pattern of differential subsidence related to synsedimentary tectonics (Gonzalez and Wetzel 1996).

\section{Samples}

Samples for this study were taken from quarry outcrops near Auenstein (Ct Aargau; hereafter AU) and Pratteln (Ct. Basel-Landschaft; hereafter PT). These consist of oolitic carbonates containing brown and greenish-yellowish-brown sphalerite, white gangue carbonate phases, and minor barite (Table 1). Two different types of sphalerite mineralization were distinguished based on mineral paragenesis (association with calcite) and host rocks (association with marl or oolitic carbonate rock). Type-1 sphalerite occurs as single crystals within marly lenses in oolitic carbonates (Fig. 3a, b) or in cavities at the interface between coarsergrained rock and finer-grained rock (Fig. 3e, f). There are no other macroscopic crystals associated with the Type- 1 sphalerite. Type-2 sphalerite is always associated with white sparry calcite and occurs as replacement or as openspace/fracture filling in oolitic carbonate host rock (Fig. 3c, d). In all samples (except for sample AU 09), white translucent calcite occurs between sphalerite and oolitic rock and fills fractures. A summary of the macroscopically identified minerals is given in Table 1. In samples AU 05 and AU 06, identification of minerals was confirmed by XRD analyses.

All samples were characterized using thin-section microscopy. Rhombohedron-shaped ankerite $\left(\mathrm{FeMgCO}_{3}\right)$ is frequently observed in carbonate rock and marl in contact with sphalerite. Framboidal pyrite (FeS) is common in marly lenses and occurs also in oolitic limestone, both in the cement and in inside oolite. Replacement of framboidal pyrite by sphalerite was not observed. Replacement of idiomorphic pyrite by sphalerite was observed in sample AU 01 (Fig. 4). 
Table 1 Description, Cd contents, and sulfur isotope composition of sphalerite samples from Auenstein (AU 01-AU 17) and Pratteln (PT 1)

\begin{tabular}{|c|c|c|c|c|c|}
\hline Samples & Dimensions of sphalerite $(\mathrm{cm})$ & Description & Paragenesis $^{\mathrm{a}}$ & $\mathrm{Cd}(\mathrm{wt} \%)$ & $\delta^{34} \mathrm{~S}(\% o, \mathrm{VCDT})$ \\
\hline \multicolumn{6}{|c|}{ Type 1 sphalerites } \\
\hline AU 01 & $1.0 \times 1.8 \times 1.0$ & $\begin{array}{l}\text { Sphalerite crystal occurs in marly lens } \\
\text { inside fractured ooid grainstone (Fig. 3a) }\end{array}$ & sl & $<0.02-0.35$ & -1.2 to -12.75 \\
\hline AU 02 & $\begin{array}{c}0.8 \times 0.5 \times 0.6 \text { and } \\
0.6 \times 0.4 \times 0.5\end{array}$ & $\begin{array}{l}\text { Sphalerite crystals occur inside a small } \\
\text { cavity (partially filled by marl) at the } \\
\text { permeability barrier in ooid grainstone }\end{array}$ & sl & & -10.4 to -11.1 \\
\hline AU 07 & $1.2 \times 1.2 \times 1.2$ & $\begin{array}{l}\text { Sphalerite occurs in marly limestone rich } \\
\text { in ankerite }\end{array}$ & sl & - & -16.8 \\
\hline AU 08 & $\begin{array}{c}0.6 \times 0.7 \times 0.6 \text { and } \\
1.5 \times 0.8 \times 0.8\end{array}$ & $\begin{array}{l}\text { Several sphalerite crystals occur inside } \\
\text { a small cavity (partially filled by marl) } \\
\text { at the permeability barrier in ooid } \\
\text { grainstone }\end{array}$ & sl & - & -9.3 \\
\hline AU 10 & $1.5 \times 1.0 \times 1.0$ & $\begin{array}{l}\text { Sphalerite crystal occurs inside a small } \\
\text { dissolution cavity (partially filled by } \\
\text { marls) in bioclastic ooid grainstone }\end{array}$ & sl & - & -14 to -16.9 \\
\hline AU 11 & $1.6 \times 0.7 \times 0.5$ & $\begin{array}{l}\text { Sphalerite crystal occurs inside a small } \\
\text { marly lens in ooid grainstone with } \\
\text { bioclasts }\end{array}$ & sl & - & -6.9 \\
\hline AU 12 & $1.0 \times 1.0 \times 1.0$ & $\begin{array}{l}\text { Sphalerite crystal occurs inside a dis- } \\
\text { solution cavity (filled by marls) in ooid } \\
\text { grainstone }\end{array}$ & sl & - & -8.7 to -10.8 \\
\hline AU 13 & $5.0 \times 1.7 \times 1.5$ & $\begin{array}{l}\text { Sphalerite crystal occurs inside a large } \\
\text { marly lens in ooid grainstone, a fracture } \\
\text { in the middle of sphalerite is filled by } \\
\text { marl }\end{array}$ & sl & $<0.02-1.3$ & -2.4 to -14 \\
\hline AU 14 & $\begin{array}{c}1.2 \times 0.8 \times 0.7 \text { and } \\
0.5 \times 0.5 \times 0.5\end{array}$ & $\begin{array}{l}\text { Sphalerite crystals occur inside a small } \\
\text { dissolution cavity (filled by marl rich } \\
\text { in ankerite) in ooid grainstone with } \\
\text { bioclasts }\end{array}$ & sl & - & -5.3 \\
\hline AU 15 & $1.5 \times 1.0 \times 1.0$ & $\begin{array}{l}\text { Sphalerite crystal occurs inside a small } \\
\text { dissolution cavity (partially filled by } \\
\text { marls rich in ankerite) in bioclastic ooid } \\
\text { grainstone }\end{array}$ & sl & $<0.02-0.5$ & -15.8 \\
\hline \multicolumn{6}{|c|}{ Type 2 sphalerites } \\
\hline AU 03 & $1.3 \times 2.5 \times 1.3$ & $\begin{array}{l}\text { Sphalerite crystal replaces ooid grainstone } \\
\text { with minor calcite mineralization }\end{array}$ & $\mathrm{sl}, \mathrm{cc}$ & $<0.02-0.6$ & -9.4 \\
\hline AU 05 & $1.2 \times 0.9 \times 0.9$ & $\begin{array}{l}\text { Sphalerite crystal replaces ooid grain- } \\
\text { stone; barite and carbonate mineraliza- } \\
\text { tions form veins and aggregates in a } \\
\text { dissolution cavity }\end{array}$ & $\begin{array}{l}\text { sl, wtz, cc, bar, } \\
\text { kut, ank, cls }\end{array}$ & - & - \\
\hline AU 06 & $2.7 \times 1.6 \times 1.7$ & $\begin{array}{l}\text { Sphalerite crystal is associated with calcite } \\
\text { replacing bioclastic ooid grainstone }\end{array}$ & sl, wurtz, cc & $<0.02-0.7$ & -10.8 \\
\hline AU 09 & $2 \times 3 \times 1.8$ & $\begin{array}{l}\text { Sphalerite crystal replacing ooid grain- } \\
\text { stone is intergrown with fibrous calcite } \\
\text { and blocky calcite mineralization }\end{array}$ & $\mathrm{sl}, \mathrm{cc}$ & - & -8.6 \\
\hline AU 16 & $3 \times 3 \times 3$ and $2 \times 2 \times 2$ & $\begin{array}{l}\text { Sphalerite crystals occur in association } \\
\text { with calcite replacing ooid grainstone } \\
\text { with bioclasts }\end{array}$ & $\mathrm{sl}, \mathrm{cc}$ & $<0.02-0.5$ & -7.3 \\
\hline AU 17 & $3 \times 3 \times 3$ and $2 \times 2 \times 2$ & $\begin{array}{l}\text { Sphalerite crystals occur in association } \\
\text { with calcite replacing ooid grainstone } \\
\text { with bioclasts, or filling fractures }\end{array}$ & $\mathrm{sl}, \mathrm{cc}$ & $<0.02-1.0$ & -6.05 to -17.9 \\
\hline PT 1 & $2.3 \times 1.5 \times 1.5$ & $\begin{array}{l}\text { Sphalerite replaces ooid grainstone with } \\
\text { subordinate calcite mineralization }\end{array}$ & $\mathrm{sl}, \mathrm{cc}$ & $0.1-1.8$ & -9.3 to -23.4 \\
\hline
\end{tabular}

a Paragenesis: ank ankerite, bar barite, $c c$ calcite, $c l s$ celestine, $k u t$ kutnohorite, $s l$ sphalerite, $w t z$ wurtzite 
Selected samples were submitted to electron microprobe analyses, $\mathrm{Rb}-\mathrm{Sr}$ and $\mathrm{Pb}-\mathrm{Pb}$ isotopic dating and tracing, and to strontium and sulfur isotope analyses. In order to determine the source of metals for sphalerite mineralization, two samples of oolitic limestone from the Hauptrogenstein formation (Bajocian age) at Auenstein, one sample of marly limestone from the Klingnau formation ( $3 \mathrm{~km}$ to the east of Auenstein, Bathonian age), and five samples of granitic and metamorphic crystalline basement rocks from the southern Black Forest massif were analyzed for $\mathrm{Pb}$ isotopes. Detailed sample descriptions and locations are given for sphalerite samples in Table 1 and for carbonate and crystalline rocks in Table 5.

\section{Analytical techniques}

Electron microprobe

Microprobe analyses were carried out on polished thin sections at the University of Lausanne (Switzerland) using an EPMA JEOL 8200 Superprobe wavelength-dispersive electron microprobe. X-ray mapping and quantitative analyses of $\mathrm{Cd}$ and $\mathrm{Fe}$ were carried out. Elemental maps were produced, and quantitative analyses were performed using WDS detectors. An accelerating voltage of $15 \mathrm{kV}$ and a current of $50 \mathrm{nA}$ were applied for elemental maps, and an accelerating voltage
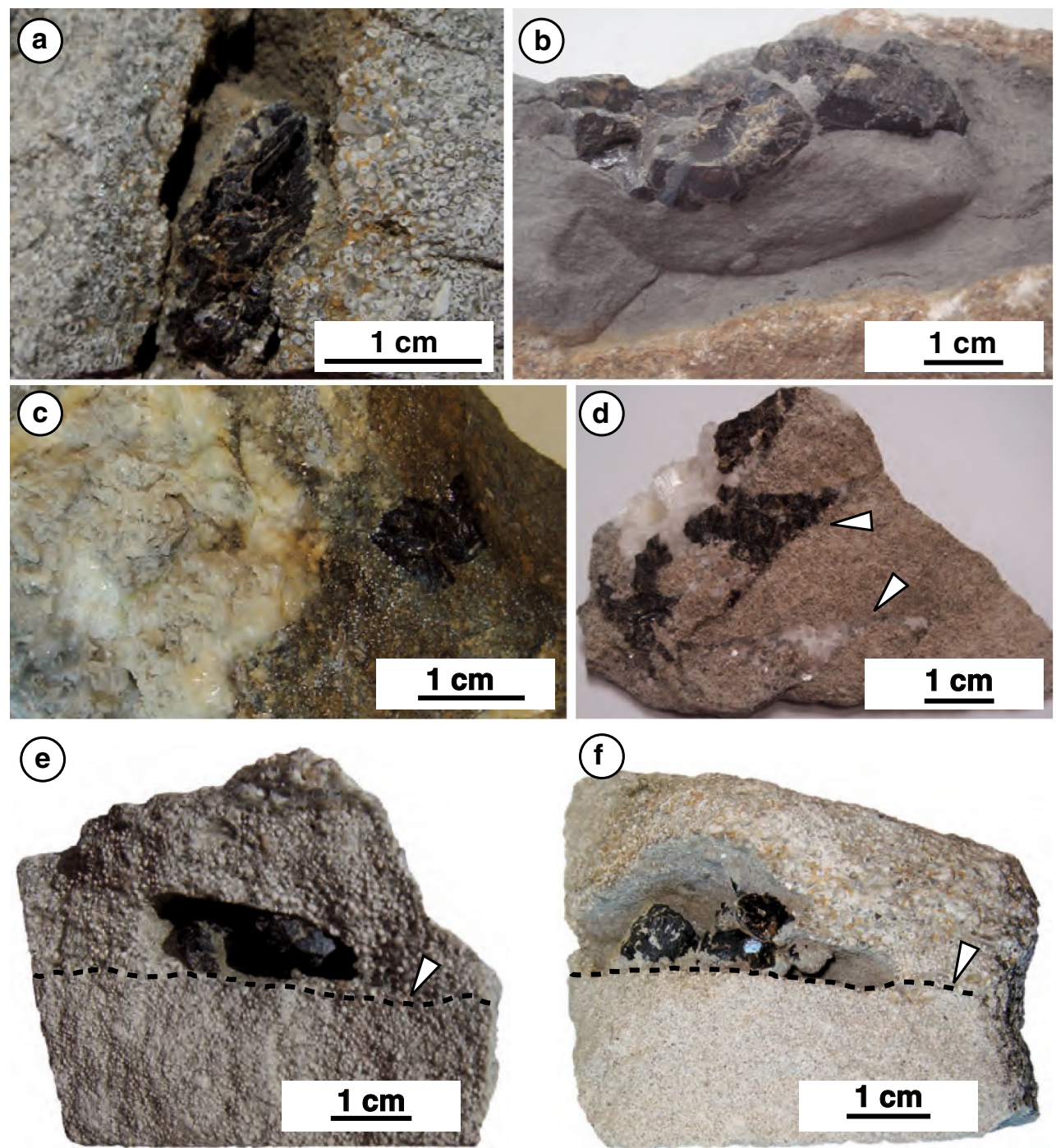

Fig. 3 Photographs of representative samples of oolitic rock containing coarse sphalerite crystals. a Sample AU 01 showing an oolitic grainstone with bioclasts, and containing a sphalerite crystal in the cavity, which is partially filled by marl, b bioclastic oolitic grainstone containing a sphalerite crystal in a marly lens (AU 13), c oolitic grainstone mineralized by barite, calcite, and celestine, with a sphalerite crystal replacing the oolitic rock (sample AU 09), d oolitic

grainstone with bioclasts (sample AU 17), containing calcite and a sphalerite mineralization associated with fractures (white arrows), $\mathbf{e}$ AU 02 and f AU 08: samples of oolitic limestone containing Type 1 sphalerite mineralization, located at the interface (black dashed line) between coarser-grained rock (upper part of samples) and finergrained rock (lower part of samples) 

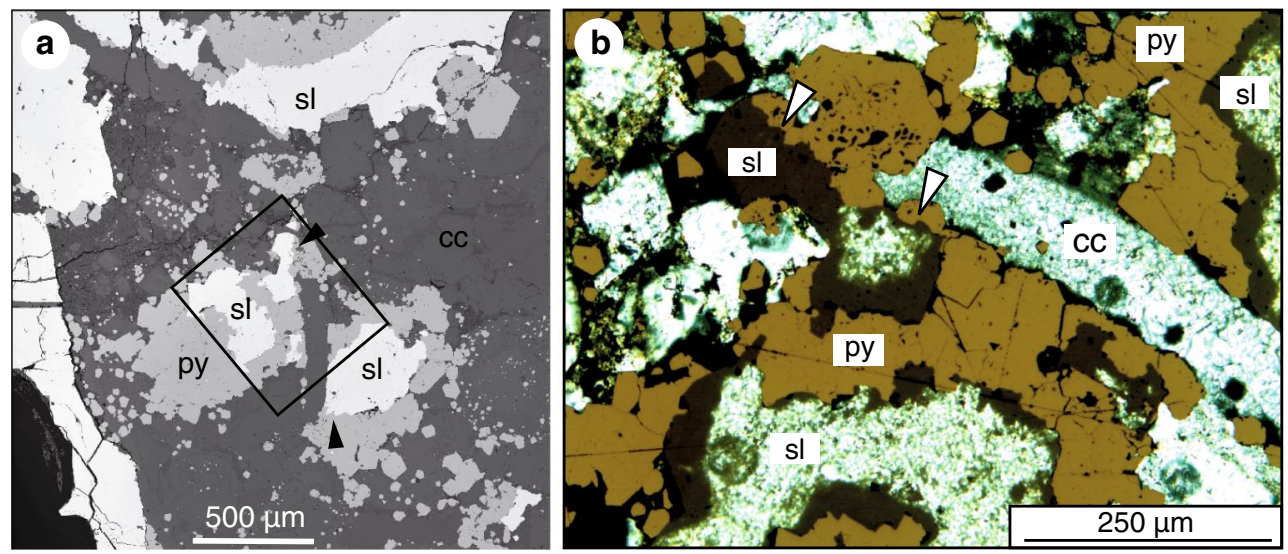

Fig. 4 Photomicrographs of AU 01 sample containing Type 1 sphalerite mineralization. $s l$ Sphalerite, $p y$ pyrite, $c c$ calcite. a Back-scattered electron image. The black frame indicates the position of the $\mathbf{b}$. Black arrows indicate areas where sphalerite replacement of pyrite

of $15 \mathrm{kV}$ and a current of $20 \mathrm{nA}$ for quantitative analysis. The counting times for all elements were $20 \mathrm{~s}$ on the peak and $10 \mathrm{~s}$ each on the high and low background. Hematite, sphalerite, and metallic $\mathrm{Cd}$ were used as calibration standards.

\section{$\mathrm{Rb}-\mathrm{Sr}$ and $\mathrm{Pb}-\mathrm{Pb}$ isotope analyses}

Two different preparation techniques were used for rock and sphalerite samples. The $\mathrm{Pb}$ and $\mathrm{Sr}$ isotope composition of crystalline rocks, bulk limestone and sphalerite sample AU 09 was determined using techniques described in Chiaradia and Fontboté (2003). Chemistry and mass spectrometry were performed at the Department of Mineralogy, University of Geneva, Switzerland. Between 160 and $170 \mathrm{mg}$ of powdered crystalline rock and about $100 \mathrm{mg}$ of marly carbonate rock (sample HDB 38) were leached at $80{ }^{\circ} \mathrm{C}$ in $3 \mathrm{M} \mathrm{HCl}$ during $12 \mathrm{~h}$ in screw-sealed Teflon beakers. The rock leachates were kept, and the residues washed twice with ultrapure water. Once dried, the residues were attacked during 7 days with $4 \mathrm{~mL}$ of concentrated $\mathrm{HF}$ and $1.5 \mathrm{~mL}$ of $15 \mathrm{M} \mathrm{HNO}_{3}$ in the screwsealed Teflon beakers and ultrasonicated every day two times/day for $30 \mathrm{~min}$. About $100 \mathrm{mg}$ of pure carbonate (samples AUN 0 and AU 4r) was dissolved in $2 \mathrm{M}$ acetic acid, and about $30 \mathrm{mg}$ of small sphalerite chips was dissolved in $2 \mathrm{~mL}$ of $3 \mathrm{M} \mathrm{HCl}$ and $1 \mathrm{~mL}$ of $15 \mathrm{M} \mathrm{HNO}_{3}$ during $36 \mathrm{~h}$ in screw-sealed Teflon beakers. After drying, the residue and leachate fractions were converted to a bromide form and lead was purified by ion-exchange chromatography on AG-MP1 resin. The Pb- and Sr-purified fractions were loaded onto Re single filaments using, respectively, the silica gel technique and a $\mathrm{TaCl}_{5}$ solution and analyzed for isotope ratios on a Finnigan Mat 262 mass spectrometer. Sr was measured at a pyrometer-controlled temperature of $1,480{ }^{\circ} \mathrm{C}$ in static mode using the can be clearly seen. b Photomicrograph taken under superposed transmitted and reflected light. White arrows indicate areas where sphalerite replacement of pyrite is clear

virtual amplifier design to cancel out biases in gain calibration among amplifiers.

The $\mathrm{Pb}$ isotope ratios were corrected for fractionation by applying a correction factor of $+0.08 \%$ /amu, based on more than 100 analyses of the international standard SRM 981 using the standard values of Todt et al. (1996). External reproducibilities of the standard ratios are $0.05 \%$ for ${ }^{206} \mathrm{~Pb} / 204 \mathrm{~Pb}, 0.08 \%$ for ${ }^{207} \mathrm{~Pb} /{ }^{204} \mathrm{~Pb}$, and $0.10 \%$ for ${ }^{208} \mathrm{~Pb} /{ }^{204} \mathrm{~Pb}$. Total lead blank contamination was $<120 \mathrm{pg}$ and, because the analyzed fractions were always $\gg 1 \mathrm{ng}$, no blank correction was necessary. ${ }^{87} \mathrm{Sr} /{ }^{86} \mathrm{Sr}$ values were internally corrected for fractionation using an ${ }^{88} \mathrm{Sr} /{ }^{86} \mathrm{Sr}$ value of 8.375209. Repeated static measurements of the SRM 987 standard in the course of this study gave an average ${ }^{87} \mathrm{Sr} /{ }^{86} \mathrm{Sr}$ of $0.710250(n=23)$.

The preparation of eight sphalerite samples and six samples of associated carbonate minerals (calcite and ankeritekutnahorite) for $\mathrm{Rb}-\mathrm{Sr}$ and $\mathrm{Pb}$ isotope analyses was done using techniques from Christensen et al. (1995a, b) and Nelson et al. (2002). Chemistry and mass spectrometry were performed at the K. U. Leuven (Belgium). About $70-150 \mathrm{mg}$ of sphalerite was handpicked from 40 to 60 mesh size fractions under a binocular microscope and then leached in $2 \mathrm{~N} \mathrm{HCl}$ to remove any carbonate. From each sphalerite sample, the fluid inclusion fraction was separated by crushing and leaching the samples in a precleaned boron carbide mortar. The inclusion fluid fractions and crushed sphalerite residues were then totally spiked using a mixed ${ }^{87} \mathrm{Rb}-{ }^{84} \mathrm{Sr}$ tracer. The latter were dissolved in Teflon vials in $6 \mathrm{~N} \mathrm{HCl}$ on a hot plate, and vial caps were repeatedly lifted to release $\mathrm{H}_{2} \mathrm{~S}$. White carbonate phases were also handpicked from 40 to 60 mesh size fractions, repeatedly rinsed and ultrasonicated in deionized water, and dried. They were then weighed, totally spiked using a mixed ${ }^{87} \mathrm{Rb}-{ }^{84} \mathrm{Sr}$ tracer solution and dissolved in $6 \mathrm{~N} \mathrm{HCl}$ on a hot plate. 
Rubidium and strontium were separated with $3 \mathrm{~N} \mathrm{HNO}_{3}$ using Eichrom $\mathrm{Sr}$ resin on $50 \mu \mathrm{L}$ Teflon columns following the methods of Deniel and Pin (2001). The first $600 \mu \mathrm{L}$ of $\mathrm{HNO}_{3}$ wash was collected for $\mathrm{Rb}$. The $\mathrm{Rb}$ cuts from the sphalerite residues were further purified using standard cation-exchange procedures (Birck 1986), whereas for the fluid inclusion liquids and the carbonate samples, no extra $\mathrm{Rb}$ separation was necessary. $\mathrm{Sr}$ was stripped from the columns with $1 \mathrm{~mL}$ of deionized water. Subsequently, the trace $\mathrm{Pb}$ contained in the sphalerite residues was eluted from the respective columns with $1 \mathrm{~mL}$ of $6 \mathrm{~N} \mathrm{HCl}$. This $\mathrm{Pb}$ cut was further processed through $50 \mu \mathrm{L}$ columns containing precleaned Eichrom Pre Filter Resin, then dried and rewetted with $1 \% \mathrm{HNO}_{3}$. For mass spectrometric analyses, $\mathrm{Pb}$ was loaded with silica gel- $\mathrm{H}_{3} \mathrm{PO}_{4}$ bedding onto Re single filaments, $\mathrm{Sr}$ was loaded with $\mathrm{TaCl}_{5}-\mathrm{HF}-\mathrm{H}_{3} \mathrm{PO}_{4}$ solution (Birck 1986) onto $\mathrm{W}$ single filaments, and $\mathrm{Rb}$ was loaded with deionized water onto the evaporation ribbon of a $\mathrm{Ta}$ double-filament assemblage. The isotope measurements were taken on a Finnigan Mat $262(\mathrm{Rb}-\mathrm{Sr})$ and a thermoelectron triton $(\mathrm{Pb})$ thermal ionization mass spectrometer running in static multicollection mode.

Repeated static measurements of the NBS 987 Sr standard during the course of this study yielded $0.71025 \pm 3$ ( $2 \sigma$ mean, $n=13$ ). Sr isotope ratios were normalized to ${ }^{86} \mathrm{Sr} /{ }^{88} \mathrm{Sr}=0.1194$; measured ${ }^{87} \mathrm{Rb} /{ }^{85} \mathrm{Rb}$ ratios were normalized using a mean fractionation factor $\delta=0.60226 \pm$ $0.11480 \% / \mathrm{amu}$ determined from repeated measurements $(n=12)$ of natural $\mathrm{Rb}$ extracted from whole-rock samples. Total procedural blanks $(n=4)$ amounted to $7-20 \mathrm{pg}$ $\mathrm{Sr} / 2 \mathrm{pg} \mathrm{Rb}$ for sphalerite residues and $15-25 \mathrm{pg} \mathrm{Sr} / 2-5 \mathrm{pg}$ $\mathrm{Rb}$ for the fluid leachates. Sr blank contributions amounted to $0.34-1.84 \%$ for the sphalerite residues and, respectively, $0.16-1.6 \%$ for the fluid leachates relative to the mass of $\mathrm{Sr}$ analyzed (c. $0.9-15 \mathrm{ng}$ ). All data were blank-corrected accordingly. Individual uncertainties $(2 \sigma)$ for $\mathrm{Rb}-\mathrm{Sr}$ elemental concentrations and isotope ratios are given in the Table 2 . $\mathrm{Rb}-\mathrm{Sr}$ model isochron regressions were calculated after Ludwig (2003) using the Isoplot/Ex version 3.00 program.

$\mathrm{Pb}$ isotope ratios of sphalerite residues were corrected for instrumental mass fractionation using a mean discrimination factor of $0.115 \pm 0.006(2 \sigma) \% / a m u$, based on replicate measurements $(n=61)$ of the SRM 981 common lead international standard. $\mathrm{Pb}$ blanks $(n=4)$ were $<20 \mathrm{pg}$ and found to be negligible. Errors and error correlations were calculated after Ludwig (1980); $2 \sigma$ uncertainties for the corrected ${ }^{206} \mathrm{~Pb} /{ }^{204} \mathrm{~Pb},{ }^{207} \mathrm{~Pb} /{ }^{204} \mathrm{~Pb}$, and ${ }^{208} \mathrm{~Pb} /{ }^{204} \mathrm{~Pb}$ ratios are $\pm 0.06,0.09$, and $0.12 \%$, respectively.

Sulfur isotope analysis

The sulfur stable isotope composition was measured at the University of Lausanne, Switzerland, by continuous flow elemental analyzer/isotope ratio mass spectrometry (EA/IRMS) using a Carlo Erba 1108 elemental analyzer connected to a Thermo Fisher (Bremen, Germany) Delta $\mathrm{V}$ Plus isotope ratio mass spectrometer. The method is discussed in detail in Herlec et al. (2010). The sulfur isotope composition is reported in the delta $(\delta)$ notation in per mil. (\%o) variations relative to Vienna Cañon Diablo Troilite standard (VCDT). Reproducibility of the laboratory standard materials (synthetic barium sulfate, $+12.5 \% \circ \delta^{34} \mathrm{~S}$; natural pyrite, $-7.0 \% \delta^{34} \mathrm{~S}$ ) was better than $\pm 0.3 \%$ (1SD). The accuracy of the $\delta^{34} \mathrm{~S}$ analyses is checked periodically by analyses of the international reference materials IAEA-S-1 and IAEA-S-2 silver sulfide $\left(-0.3\right.$ and $\left.+22.7 \pm 0.2 \% \circ \delta^{34} \mathrm{~S}\right)$ and NBS-123 sphalerite $(+17.09 \pm 0.31 \%$ o). For some samples, several subsamples were taken with a dental drill from each crystal in the hand specimen, in order to evaluate the variation of $\delta^{34} \mathrm{~S}$ inside single crystals, as well as among crystals in the same sample.

\section{Results}

Electron microprobe analyses (EMP)

The concentrations of $\mathrm{Cd}$ and $\mathrm{Fe}$ in sphalerite vary from $<0.02$ to 1.8 and $<0.04$ to $1.14 \mathrm{wt} \%$, respectively (Table 1 ). The Cd concentrations fall within the range of typical concentrations $(0.2-1.0 \mathrm{wt} \%)$ for this element in sphalerite (Cook et al. 2009). Cd and Fe X-ray element distribution maps of selected sphalerite samples show that the distribution of $\mathrm{Cd}$ and $\mathrm{Fe}$ within the crystals is inhomogeneous (Fig. 5). An X-ray intensity map of $\mathrm{Cd}$ and $\mathrm{Fe}$ in the Type-1 sphalerite shows sector zoning (AU 1, AU 10, AU 13, and AU 15) and the existence of large zones (more than $4 \mathrm{~mm}$ ) with an apparently homogeneous $\mathrm{Cd}$ distribution. Overgrowth and crystal twinning were not observed in the sphalerite samples, which indicates that Type- 1 sphalerite represents single crystals, most probably slowly precipitated during a single mineralization event.

Crystal twinning and twinning planes were observed in Type-2 sphalerite (AU 17 and PT 1; indicated by elongated rectangular pattern of elemental zonation, black arrow in Fig. 5), which suggests that Type-2 sphalerite represents an aggregate of crystals co-precipitated under physicochemical conditions different from Type-1 sphalerite. An X-ray intensity map of $\mathrm{Cd}$ and $\mathrm{Fe}$ in sample PT 1 (Fig. 6) shows oscillatory growth zonation for both elements: Cd-rich zones (up to $1.3 \mathrm{wt} \% \mathrm{Cd}$ ) alternate with zones depleted in $\mathrm{Cd}$ (up to $0.4 \mathrm{wt} \% \mathrm{Cd}$ ). Oscillatory growth banding (band width of 1-10 mm) in sphalerite was shown by Fowler and L'Heureux (1996) to originate when the crystal forms in non-equilibrium conditions, resulting most probably from 
Table $2 \mathrm{Rb}-\mathrm{Sr}$ isotope data and $\mathrm{Rb}$ and $\mathrm{Sr}$ concentrations for sphalerite residues (R), sphalerite fluid inclusion leachates (L), associated carbonate mineralizations (cc, kut/ank), and oolitic limestone (AU 4r)

${ }^{\mathrm{a}} \mathrm{Rb}$ and $\mathrm{Sr}$ concentrations of fluid inclusions are not reported since the total amount of trapped fluid in the samples is not known

\begin{tabular}{lcccc}
\hline Sample & ${ }^{87} \mathrm{Rb} /{ }^{86} \mathrm{Sr} \pm 2 \sigma$ & ${ }^{87} \mathrm{Sr} /{ }^{86} \mathrm{Sr} \pm 2 \sigma$ & $\mathrm{Rb}(\mathrm{ppm}) \pm 2 \sigma$ & $\mathrm{Sr}(\mathrm{ppm}) \pm 2 \sigma$ \\
\hline Crushed-leached sphalerite residues $(\mathrm{R})$ & & & \\
AU 11 R (Type 1) & $2.3545 \pm 0.0238$ & $0.71429 \pm 0.00003$ & $0.02204 \pm 0.00019$ & $0.0271 \pm 0.0002$ \\
AU 13 R (Type 1) & $2.7353 \pm 0.0282$ & $0.71513 \pm 0.00002$ & $0.01265 \pm 0.00011$ & $0.0134 \pm 0.0001$ \\
AU 14 R (Type 1) & $2.6733 \pm 0.0299$ & $0.71495 \pm 0.00005$ & $0.02099 \pm 0.00022$ & $0.0227 \pm 0.0002$ \\
AU 15 R (Type 1) & $1.5899 \pm 0.0161$ & $0.71249 \pm 0.00003$ & $0.00869 \pm 0.00008$ & $0.0158 \pm 0.0001$ \\
AU 05 R (Type 2) & $2.1220 \pm 0.0336$ & $0.71204 \pm 0.00003$ & $0.01087 \pm 0.00009$ & $0.0148 \pm 0.0002$ \\
AU 09 R (Type 2) & $0.7492 \pm 0.0097$ & $0.70764 \pm 0.00009$ & $0.00158 \pm 0.00001$ & $0.0061 \pm 0.0001$ \\
AU 16 R (Type 2) & $0.8683 \pm 0.0097$ & $0.70824 \pm 0.00004$ & $0.00223 \pm 0.00002$ & $0.0074 \pm 0.0001$ \\
AU 17 R (Type 2) & $0.5088 \pm 0.0053$ & $0.71202 \pm 0.00002$ & $0.00225 \pm 0.00002$ & $0.0128 \pm 0.0001$ \\
Fluid inclusion leachates $(\mathrm{L})$ & & & - \\
AU 11 L (Type 1) & $0.1973 \pm 0.0030$ & $0.70767 \pm 0.00005$ & - & - \\
AU 13 L (Type 1) & $0.1360 \pm 0.0015$ & $0.70749 \pm 0.00001$ & - & - \\
AU 14 L (Type 1) & $0.1557 \pm 0.0018$ & $0.70768 \pm 0.00005$ & - & - \\
AU 15 L (Type 1) & $0.0717 \pm 0.0009$ & $0.70797 \pm 0.00002$ & - & - \\
AU 05 L (Type 2) & $0.0364 \pm 0.0005$ & $0.70726 \pm 0.00003$ & - & - \\
AU 09 L (Type 2) & $0.2005 \pm 0.0021$ & $0.70931 \pm 0.00004$ & - & - \\
AU 16 L (Type 2) & $0.0406 \pm 0.0035$ & $0.70755 \pm 0.00007$ & - & - \\
AU 17 L (Type 2) & $0.0184 \pm 0.0012$ & $0.70752 \pm 0.00003$ & - & 2.0 .7 \\
Associated carbonates and oolitic limestone & & & - \\
AU 05 cc & $0.000076 \pm 0.000002$ & $0.70716 \pm 0.00001$ & $0.0056 \pm 0.0001$ & - \\
AU 05 (kut/ank?) & $0.000221 \pm 0.000008$ & $0.70732 \pm 0.00002$ & $0.0231 \pm 0.0007$ & $302.0 \pm 2.6$ \\
AU 09 cc & $0.000306 \pm 0.000009$ & $0.70719 \pm 0.00001$ & $0.0271 \pm 0.0006$ & $256.2 \pm 2.2$ \\
AU 16 cc & $0.000026 \pm 0.000001$ & $0.70726 \pm 0.00001$ & $0.0038 \pm 0.0001$ & $415.5 \pm 3.7$ \\
AU 17 cc & $0.000051 \pm 0.000002$ & $0.70727 \pm 0.00002$ & $0.0048 \pm 0.0001$ & $270.7 \pm 2.4$ \\
AU 17 cc 2 & $0.033943 \pm 0.000812$ & $0.70733 \pm 0.00001$ & $3.0930 \pm 0.0585$ & $263.3 \pm 2.3$ \\
AU 4r & - & $0.707170 \pm 0.000004$ & - & - \\
\hline
\end{tabular}

the mixing of two different solutions (metal-bearing solution and sulfur-bearing solution). Additionally, sample PT 1 consists probably of two Type- 2 sphalerite generationsa first sphalerite with oscillatory zoning, discussed above, and a second generation presents as a cluster of sphalerite poor in $\mathrm{Fe}$ and $\mathrm{Cd}$ (up to $0.3 \mathrm{wt} \%$; Fig. 6). The second sphalerite may have replaced carbonate grains (oolithes?), which were overgrown by the first sphalerite. A reaction rim separates the two sphalerite generations (Fig. 6). We conclude therefore that sample PT 1 does not represent a closed system since its formation and cannot be used for $\mathrm{Rb}-\mathrm{Sr}$ dating. We did not observe overgrowth in the other sphalerite samples, which suggests that the crystals were most probably formed during a single mineralization event.

\section{$\mathrm{Rb}-\mathrm{Sr}$ geochronology}

The results of $\mathrm{Rb}$ and $\mathrm{Sr}$ isotope analyses are given in Table 2. The Sr isotope composition of the oolitic carbonate rock is $0.707170 \pm 0.000004$. The sphalerite residues have ${ }^{87} \mathrm{Rb} /{ }^{86} \mathrm{Sr}$ ratios between $0.51 \pm 0.02$ and $2.73 \pm 0.03$, and ${ }^{87} \mathrm{Sr} /{ }^{86} \mathrm{Sr}$ ratios between $0.70764 \pm 0.00009$ and $0.71513 \pm 0.00002$. Type- 1 sphalerite, crystallized in marly lenses, display higher ${ }^{87} \mathrm{Sr} /{ }^{86} \mathrm{Sr}$ isotope ratios than Type-2 sphalerite, associated with translucent calcite.

In a ${ }^{87} \mathrm{Sr} /{ }^{86} \mathrm{Sr}$ versus ${ }^{87} \mathrm{Rb} /{ }^{86} \mathrm{Sr}$ diagram (Fig. 7), Type-1 sphalerite samples define a regression line (mean square weighted deviation, MSWD = 1.3) with a slope corresponding to an isochron model age of 162.0 $\pm 4.1 \mathrm{Ma}$ and a model initial Sr with ${ }^{87} \mathrm{Sr} /{ }^{86} \mathrm{Sr}_{\text {initial }}=0.7088 \pm 0.0001$. This age corresponds within the uncertainty to the CallovianLate Oxfordian stages (Gradstein et al. 2012). The MSWD of 1.3 indicates that the data scatter slightly exceeds that predicted from the number of samples and the analytical precision alone (Wendt and Carl 1991). This excess scatter may be due to slight variations in the ${ }^{87} \mathrm{Sr} /{ }^{86} \mathrm{Sr}_{\text {initial }}$ among the studied sulfides. The fit of fluid leachate AU $09 \mathrm{~L}$ is possibly coincidental, as we do not know whether most of the fluid inclusions in this sample is primary or not. An internal, three-point model isochron calculated for the sphalerite residue (R)-fluid leachate (L)-calcite (cc) triplet of Type-2 sample AU 05 yields an age of $162.0 \pm 2.8 \mathrm{Ma}$ $\left(\mathrm{MSWD}=2.0 ;{ }^{87} \mathrm{Sr} /{ }^{86} \mathrm{Sr}_{\text {initial }}=0.70716 \pm 0.00009\right)$. This 

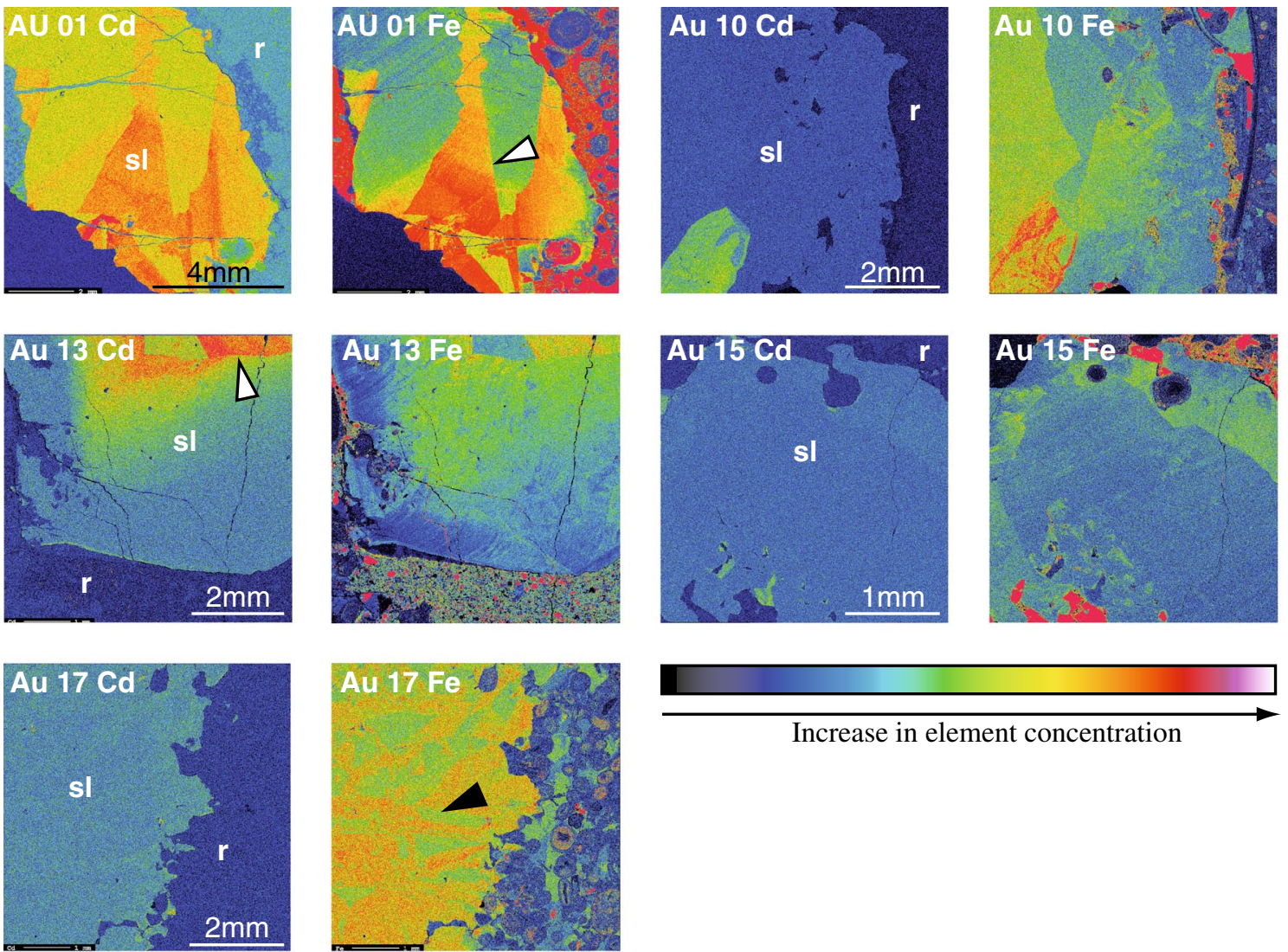

Increase in element concentration

Fig. 5 Electron microprobe (EMP) Cd and Fe mapping images of a sphalerite crystals from samples AU 01, AU10, AU 13, AU 15, and AU 17. $s l$ Sphalerite, $r$ host rock. White arrows indicate sector zoning in sphalerite crystals; black arrow indicates crystal twinning in the sample AU 17

apparent age is concordant within errors with the four-point model isochron age defined by the Type-1 sphalerite residues, but the initial ${ }^{87} \mathrm{Sr} /{ }^{86} \mathrm{Sr}$ ratio is lower.

\section{Lead isotopes}

The $\mathrm{Pb}$ isotope results are given in Table 3 . The residues of crystalline rocks are, as expected from systematic measurements of Chiaradia and Fontboté (2003), always less radiogenic than the corresponding leachates (Fig. 8). The $\mathrm{Pb}$ isotope composition of sedimentary rock falls within the isotopic field of granitic rocks. The oolitic limestone hosting sphalerite is more radiogenic than that from a nonmineralized horizon. Both leachate and residue from marly limestone are more radiogenic than oolitic limestone.

The $\mathrm{Pb}$ isotope composition of sphalerite residues is very uniform $\left({ }^{206} \mathrm{~Pb} /{ }^{204} \mathrm{~Pb}=18.63-18.67 ;{ }^{207} \mathrm{~Pb} /{ }^{204} \mathrm{~Pb}=15.63-\right.$ 15.64; ${ }^{208} \mathrm{~Pb} /{ }^{204} \mathrm{~Pb}=38.51-38.63$; Fig. 8). It is more radiogenic than that of non-mineralized oolitic carbonate rock $\left({ }^{206} \mathrm{~Pb} /{ }^{204} \mathrm{~Pb}=18.63 ;{ }^{207} \mathrm{~Pb} /{ }^{204} \mathrm{~Pb}=15.62\right.$; $\left.{ }^{208} \mathrm{~Pb} /{ }^{204} \mathrm{~Pb}=38.50\right)$ and of the residues of crystalline basement rocks.

\section{Sulfur isotopes}

The $\delta^{34} \mathrm{~S}$ values of sphalerite from Auenstein and Pratteln vary from -22 to $-7.3 \%$ (average $-11.2 \pm 5.4 \%$, median $-10.80 \%, n=42$; Table 1$)$. Type-1 and Type-2 sphalerites have similar $\delta^{34} \mathrm{~S}$ values, $-9.0 \pm 5.1$ and $-13.0 \pm 5.0 \%$, respectively (Fig. 9). Barite sample AU 05 has a sulfur isotope signature of $13.6 \%$, which is slightly lighter than values of Middle-Late Jurassic seawater determined from structurally substituted sulfate (moving average $16.7 \pm 1.7-16.9 \pm 1.7 \%$; Kampschulte and Strauss 2004) and marine evaporitic sulfate (moving average $16.6 \pm 0.8-17.1 \pm 1.5 \%$; Strauss 1997, 1999).

\section{Discussion}

Based on the obtained results, we can constrain the mineralizing process and precipitation mechanism of sphalerite and situate this mineralizing event in a larger geological context. 
a

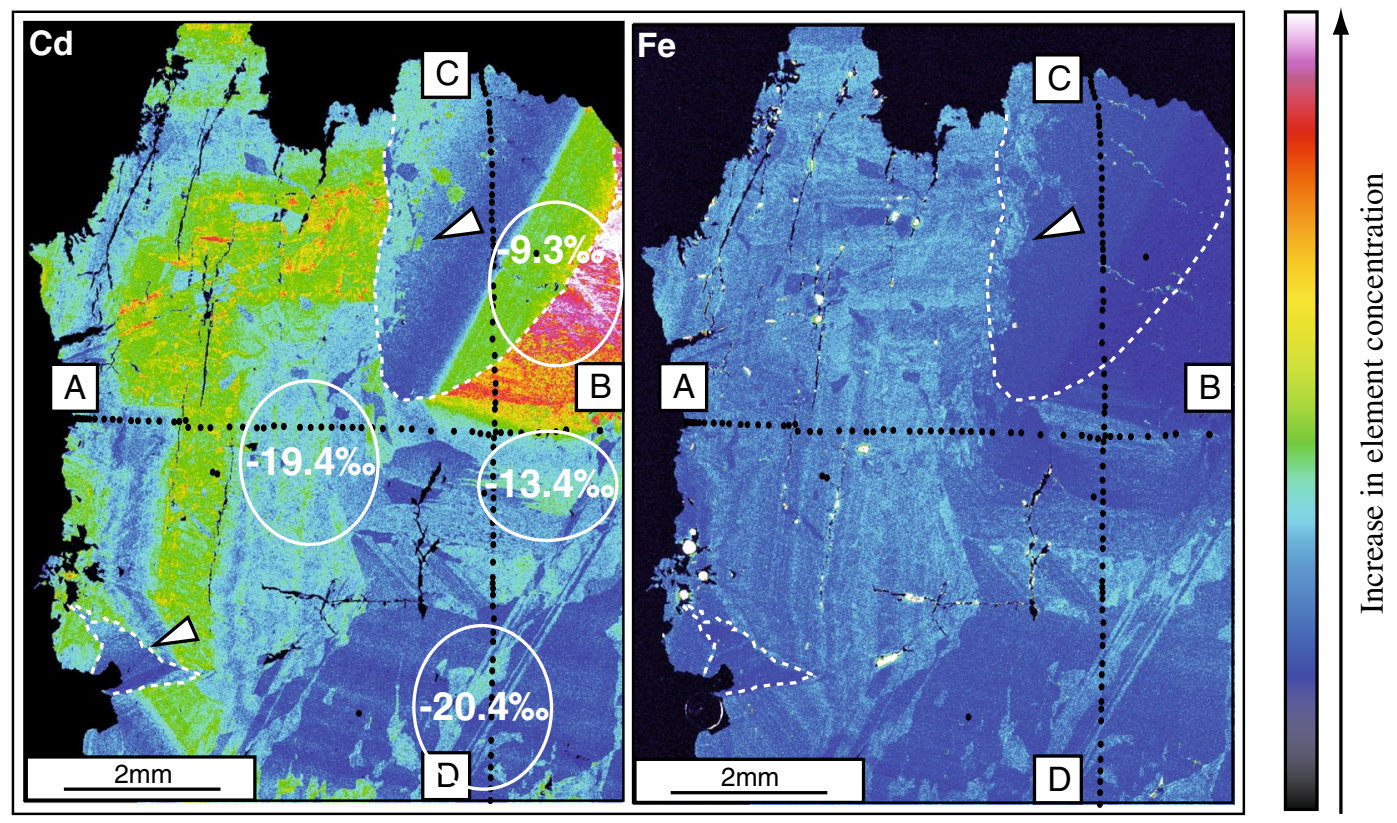

b
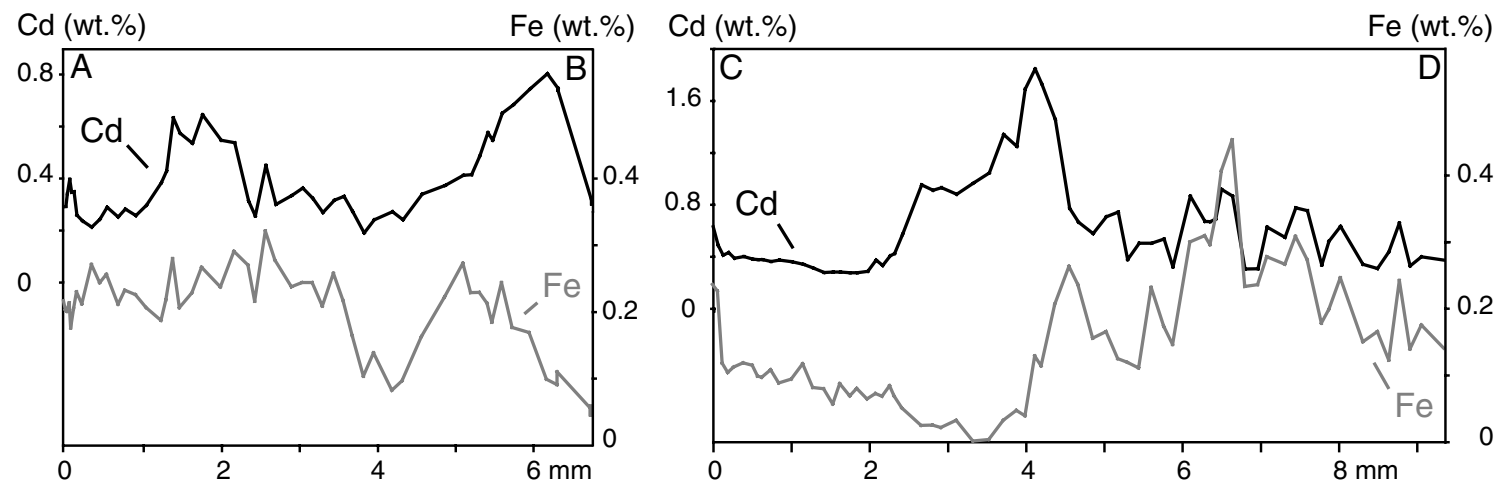

Fig. 6 a Electron microprobe (EMP) $\mathrm{Cd}$ and $\mathrm{Fe}$ mapping images of a sphalerite crystal from sample PT 1. The EMP map shows growth banding of $\mathrm{Cd}$ and $\mathrm{Fe}$ in primary sphalerite 1, and textures of corrosion (white arrows) during the later precipitation of sphalerite 2 (upper right). White dashed line indicates the position of boundary between sphalerite 1 and sphalerite 2 . Second-generation sphalerite has Fe concentrations lower than the partially corroded primary sphalerite, whereas changes in $\mathrm{Cd}$ concentrations between the two sphalerite generations are more complex. Black dots are the position of measurements with WDS detector along two profiles. White circles correspond to the position of subsamples taken for sulfur isotope analyses; numbers correspond to measured $\delta^{34} \mathrm{~S}$ values (in \%o). b A plot of point-by-point analyses of $\mathrm{Cd}$ and $\mathrm{Fe}$ contents versus distance along traverses $A-B$ and $C-D$, which are shown on the figure above
Source of sulfur

The negative and relatively inhomogeneous $\delta^{34} \mathrm{~S}$ values allow to put constraints on the source of sulfur for sphalerite.

The source of reduced sulfur to the mineralizing fluid in sedimentary environments can be (1) bacterial reduction in seawater sulfate (BSR), (2) replacement/dissolution of biogenic pyrite, (3) thermal decomposition of organic matter, and (4) thermochemical reduction in sulfate by organic and inorganic compounds, including reactive organic molecules and $\mathrm{Fe}^{2+}$ (Ohmoto and Goldhaber 1997). The first three processes produce ${ }^{34} \mathrm{~S}$-depleted reduced sulfur due to the significant kinetic isotopic fractionation induced by sulfatereducing bacteria, whereas the last one provides isotopically heavy sulfur with positive $\delta^{34} \mathrm{~S}$ values, requires relatively high temperatures ( $>80{ }^{\circ} \mathrm{C}$; Machel et al. 1995), and is unlikely to have occurred in the sedimentary environment at Auenstein.

Reduction in seawater sulfate in sediments occurs below the sediment-water interface by anaerobic bacteria using an organic carbon substrate as electron donor. The sulfide 


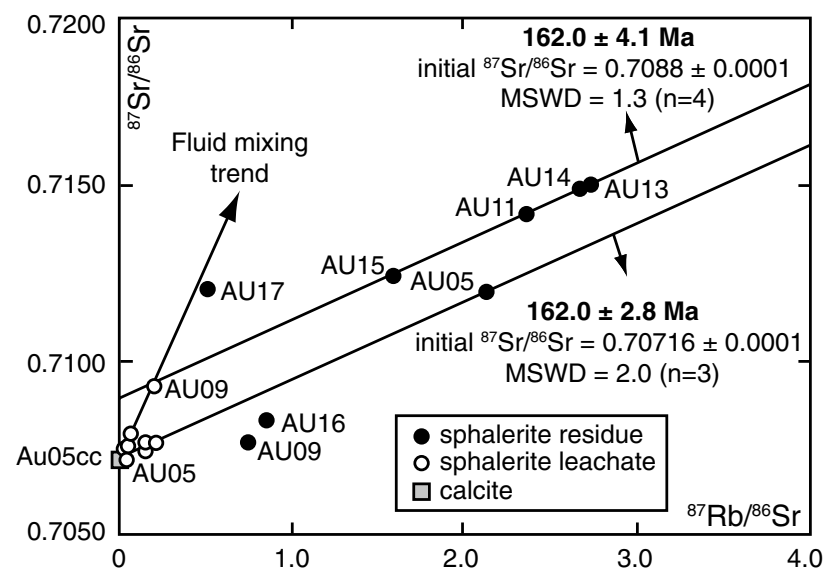

Fig. $7{ }^{87} \mathrm{Sr} /{ }^{86} \mathrm{Sr}$ versus ${ }^{87} \mathrm{Rb} /{ }^{86} \mathrm{Sr}$ diagram showing sphalerite residues and complementary leachates. $2 \sigma$ values are given in Table 2

Table 3 Lead isotope composition of bulk (B) and crushed-leached residues $(\mathrm{R})$ of sphalerites, of residue and leachate fractions of crystalline rocks of the southern Black Forest Massif, and of limestone from Auenstein

\begin{tabular}{|c|c|c|c|}
\hline Sample & ${ }^{206} \mathrm{~Pb} /{ }^{204} \mathrm{~Pb}$ & ${ }^{207} \mathrm{~Pb} /{ }^{204} \mathrm{~Pb}$ & ${ }^{208} \mathrm{~Pb} /{ }^{204} \mathrm{~Pb}$ \\
\hline \multicolumn{4}{|c|}{ Sphalerite residues (R) and bulk sphalerite (B) } \\
\hline AU $05 \mathrm{R}$ & 18.672 & 15.639 & 38.634 \\
\hline AU 09 B & 18.646 & 15.627 & 38.530 \\
\hline AU $09 \mathrm{R}$ & 18.650 & 15.636 & 38.599 \\
\hline AU $11 \mathrm{R}$ & 18.638 & 15.637 & 38.575 \\
\hline AU $13 \mathrm{R}$ & 18.655 & 15.640 & 38.622 \\
\hline AU $14 \mathrm{R}$ & 18.647 & 15.635 & 38.584 \\
\hline AU $15 \mathrm{R}$ & 18.631 & 15.632 & 38.507 \\
\hline AU $16 \mathrm{R}$ & 18.629 & 15.631 & 38.531 \\
\hline AU $17 \mathrm{R}$ & 18.626 & 15.631 & 38.522 \\
\hline \multicolumn{4}{|c|}{ Limestone leachates $(\mathrm{L})$, residues $(\mathrm{R})$ and bulk rock $(\mathrm{B})$} \\
\hline AUNO B & 18.627 & 15.617 & 38.499 \\
\hline $\mathrm{AU} 4 \mathrm{r} \mathrm{B}$ & 18.823 & 15.641 & 38.731 \\
\hline HDB $38 \mathrm{~L}$ & 18.851 & 15.630 & 38.866 \\
\hline HDB $38 \mathrm{R}$ & 18.912 & 15.621 & 38.679 \\
\hline \multicolumn{4}{|c|}{ Crystalline rocks leachates $(\mathrm{L})$} \\
\hline $\mathrm{Pb} 5035 \mathrm{~L}$ & 21.751 & 15.819 & 41.276 \\
\hline $\mathrm{Pb} 5034 \mathrm{~L}$ & 18.650 & 15.629 & 38.614 \\
\hline $\mathrm{Pb} 5036 \mathrm{~L}$ & 18.470 & 15.597 & 38.890 \\
\hline $\mathrm{Pb} 5037 \mathrm{~L}$ & 24.756 & 15.920 & 45.631 \\
\hline $\mathrm{Pb} 5038 \mathrm{~L}$ & 23.052 & 15.834 & 43.788 \\
\hline \multicolumn{4}{|c|}{ Crystalline rocks residues (R) } \\
\hline $\mathrm{Pb} 5035 \mathrm{R}$ & 18.397 & 15.640 & 38.396 \\
\hline $\mathrm{Pb} 5034 \mathrm{R}$ & 18.210 & 15.588 & 38.044 \\
\hline $\mathrm{Pb} 5036 \mathrm{R}$ & 18.317 & 15.570 & 38.216 \\
\hline $\mathrm{Pb} 5037 \mathrm{R}$ & 18.509 & 15.566 & 38.146 \\
\hline $\mathrm{Pb} 5038 \mathrm{R}$ & 18.423 & 15.572 & 38.161 \\
\hline
\end{tabular}

produced during bacterial sulfate reduction is significantly enriched in ${ }^{32} \mathrm{~S}$ due to kinetic isotope fractionation, and the $\Delta_{\text {sulfide-sulfate }}$ changes from $-50 \pm 20$ to $-45 \pm 20 \%$ o during the burial to a depth of $\sim 2 \mathrm{~m}$, as the system becomes partially closed (Ohmoto and Goldhaber 1997). Therefore, during the biogenic reduction in Middle-Late Jurassic seawater sulfate with $\delta^{34} \mathrm{~S}$ values close to $17 \%$, the $\delta^{34} \mathrm{~S}$ values of $\mathrm{H}_{2} \mathrm{~S}$ may have been in the range of -50 to $-8 \%$ o and may have even shifted toward more positive values with time and increasing closeness of the system. However, the residence time of free biogenic $\mathrm{H}_{2} \mathrm{~S}$ produced by bacterial seawater sulfate reduction is relatively short, due to different processes: (1) $\mathrm{H}_{2} \mathrm{~S}$ escape to the overlying oxygenated sediments and water column; (2) precipitation of iron sulfides with low $\delta^{34} \mathrm{~S}$ values $(-25 \pm 20 \%$ o), when reactive $\mathrm{Fe}^{2+}$ is available; and (3) the interaction with organic matter to form organically bound sulfur after complete consumption of $\mathrm{Fe}^{2+}$ (Ohmoto and Goldhaber 1997). During later diagenesis, the decomposition of pyrite and chemical and thermal decomposition of sedimentary organic matter by hydrothermal fluids may release isotopically light, reduced, sulfur species, which may participate in precipitation of metal sulfides in the host sediments (Ohmoto and Goldhaber 1997).

The abundance of early diagenetic framboidal pyrite in oolitic limestone and marl at Auenstein suggests that in addition to organic matter, pyrite may represent a source of reduced sulfur during the formation of sphalerite. The $\delta^{34} \mathrm{~S}$ values of biogenic pyrites cover a broad range and are typically of $\sim 20 \%$, but during replacement reactions, remobilization and homogenization of sulfide may occur, and the resulting sphalerite may have less spread in $\delta^{34} \mathrm{~S}$ values than the original pyrite (Ohmoto and Goldhaber 1997). Therefore, we consider that the negative $\delta^{34} \mathrm{~S}$ values in sphalerite samples at Auenstein and Pratteln with a spread of $22 \%$ o ( -1.2 to $-23.4 \%$ ) are compatible with a sulfide sulfur contribution from the decomposition of early diagenetic pyrite and organic sulfur compounds.

The relatively low $\delta^{34} \mathrm{~S}$ values of barite in the sample AU 5 may be explained by a contribution of isotopically light sulfur from the oxidative degradation of organo-sulfur compounds or pyrite, as the sulfur isotope fractionation between seawater sulfate and precipitated sulfate is usually small $(<0.5 \%$ o, Ohmoto and Rye 1979).

$\mathrm{Rb}-\mathrm{Sr}$ age and isotope systematics of sphalerite

Type-1 sphalerite residues are well correlated in the ${ }^{87} \mathrm{Sr} /{ }^{86} \mathrm{Sr}$ versus ${ }^{87} \mathrm{Rb} /{ }^{86} \mathrm{Sr}$ diagram and define a regression line, which can be interpreted as a four-point isochron with age significance, whereas most of the Type- 2 sphalerites scatter largely around this line (Fig. 7). The corresponding sphalerite residue (R)-fluid leachate (L)-calcite (cc) triplet 
a

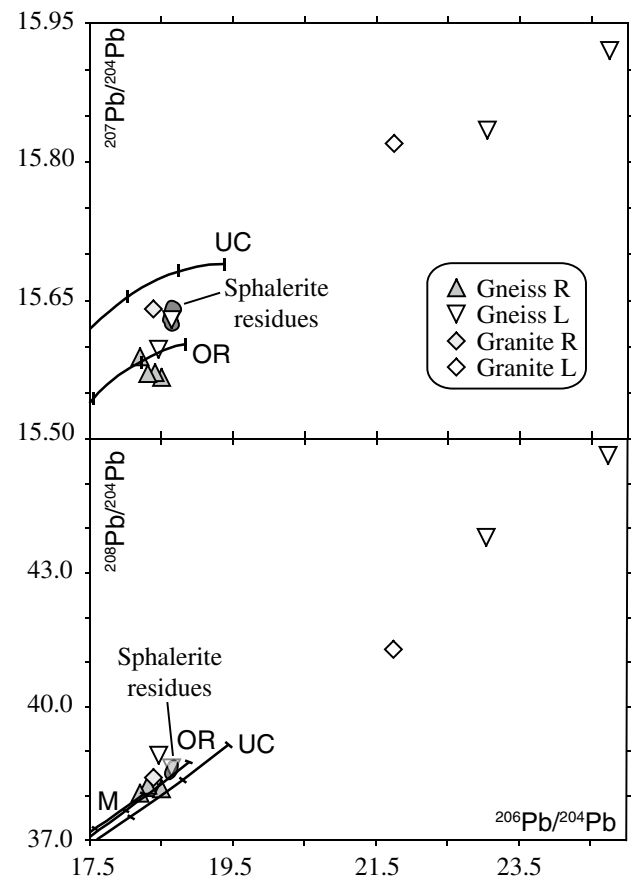

Fig. 8 Lead isotope composition of sphalerite samples from Auenstein compared to the carbonate rock of Bajocian age from the northwestern Jura Mountains and to the crystalline basement rocks from the southern Black Forest Massif. a ${ }^{207} \mathrm{~Pb} /{ }^{204} \mathrm{~Pb}$ and ${ }^{208} \mathrm{~Pb} /{ }^{204} \mathrm{~Pb}$ versus ${ }^{206} \mathrm{~Pb} /{ }^{204} \mathrm{~Pb}$ plots for sphalerites and leachates and residues of granitic and metamorphic rocks. $b^{207} \mathrm{~Pb} /{ }^{204} \mathrm{~Pb}$ and ${ }^{208} \mathrm{~Pb} /{ }^{204} \mathrm{~Pb}$ versus

of Type 2 sample AU 05 also forms a statistically wellsupported line, giving an age, which is concordant within errors with the Type-1 sphalerite isochron. We therefore consider the ca. $162 \mathrm{Ma}$ age derived from both isochron regressions to be geochronologically meaningful and geologically realistic. It reliably reflects an event of epigenetic sulfide mineralization in the host rock of Middle Bajocian age during the Callovian-Late Oxfordian.

The scatter of the remaining three Type 2 sphalerites (Fig. 7) can be explained by (1) a non-coeval formation of Type- 1 and most Type-2 sphalerites, or (2) a coeval formation but later disturbance of the $\mathrm{Rb}-\mathrm{Sr}$ system in the Type-2 sphalerites. In a ${ }^{87} \mathrm{Sr} /{ }^{86} \mathrm{Sr}$ versus $1 /{ }^{86} \mathrm{Sr}$ mixing plot (Fig. 10a; cf. Pettke and Diamond 1996), all Type-1 sphalerites are not correlated, whereas Type-2 sphalerites reflect a negatively correlated linear trend, which indicates a progressive loss of $\mathrm{Sr}$ relative to the compositions of Type- 1 sphalerites. Additionally, in the $1 / \mathrm{Rb}$ versus ${ }^{87} \mathrm{Rb} /{ }^{86} \mathrm{Sr}$ space, most Type- 2 samples display also a drastic $\mathrm{Rb}$ depletion compared to Type-1 sphalerites (Fig. 10b; cf. Pettke and Diamond 1996). We interpret these systematic $\mathrm{Rb}-\mathrm{Sr}$ elemental and isotopic shifts in Type-2 sphalerites to be consistent with later fluid-induced disturbances, most likely caused by (in b



${ }^{206} \mathrm{~Pb} /{ }^{204} \mathrm{~Pb}$ plots showing sphalerite residues, carbonate rocks from the northwestern Jura Mountains and crystalline rocks compared to literature data for metamorphic rocks (1), granitic rocks (2), and associated K-feldspars (3) from the southern Black Forest Massif (from Kober and Lippolt 1985). Evolution curves ( $M$ mantle, $U C$ upper crust, $O R$ orogen) are from Zartman and Doe (1981)

situ) recrystallization or remobilization and reprecipitation processes involving Type- 1 sphalerites. This is supported by EMP analyses (sample PT 1), which indicate the presence of two sphalerite generations displaying dissolution/reprecipitation textures. It appears, however, that not all Type-2 sphalerites from Auenstein are products of this disturbance, as Type- 2 sample AU 05 reflects isotope systematics similar to Type- 1 sphalerites and also gives an identical age.

Fluid origin and metal source

The initial $\mathrm{Sr}$ isotope signature indicated by the $\mathrm{AU}$ 05 three-point isochron $\left({ }^{87} \mathrm{Sr} /{ }^{86} \mathrm{Sr}=0.70716\right)$ matches the $\mathrm{Sr}$ isotopic composition of the carbonate host rock $\left({ }^{87} \mathrm{Sr} /{ }^{86} \mathrm{Sr}=0.70717\right)$, and both values are in the range of values observed for contemporaneous Middle Jurassic (Bajocian-Bathonian) seawater $\left({ }^{87} \mathrm{Sr} /{ }^{86} \mathrm{Sr}=0.7070\right.$ 0.7073; Jones et al. 1994). The same applies to ${ }^{87} \mathrm{Sr} /{ }^{86} \mathrm{Sr}$ isotope ratios of sparry carbonates associated with Type-2 sphalerite at Auenstein (Table 2). This suggests that the initial $\mathrm{Sr}$ in the AU 05 sphalerite-calcite association and the other Type- 2 mineralization calcites were exclusively derived from the oolitic host limestone. 


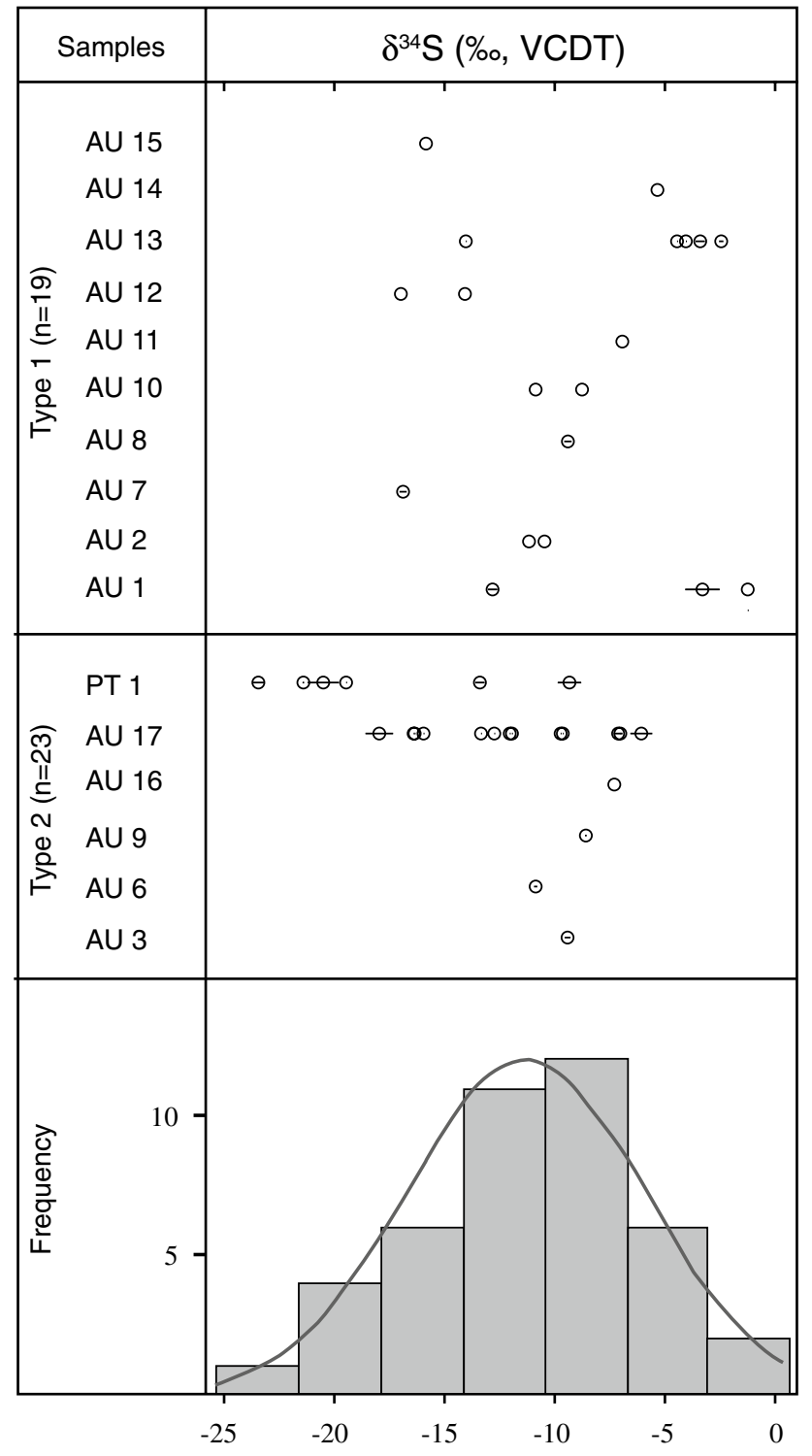

Fig. 9 Range of $\delta^{34} \mathrm{~S}$ values for sphalerite found at Auenstein and Pratteln in oolitic rock of Bajocian age. Subsamples of the same sample are shown separately. Error bars are shown for powder of the same subsample analyzed several (2-4) times

Conversely, the initial ${ }^{87} \mathrm{Sr} /{ }^{86} \mathrm{Sr}$ ratio of c. 0.7088 reflected by the Type-1 sphalerite isochron is higher and falls outside the range of marine ${ }^{87} \mathrm{Sr} /{ }^{86} \mathrm{Sr}$ signatures reported for Triassic and Jurassic carbonate rocks $\left({ }^{87} \mathrm{Sr} /{ }^{86} \mathrm{Sr}=0.70685-0.7083\right.$; McArthur et al. 2001). However, the Type-1 sphalerite isochron intersects a steep linear trend defined by certain sphalerite inclusion fluids (Figs. 7, 11), which indicates binary mixing of $\mathrm{Sr}$ mobilized from the carbonate host rocks (source 1) and radiogenic Sr from external sources (source 2), which also provided $\mathrm{Rb}$. We therefore conclude that the elevated initial $\mathrm{Sr}$ isotope signature of Type 1 sphalerite represents an isotopic mixture that was generated by interaction of mineralizing external fluids with the carbonate host rocks. The isotope characteristics of external "source 2" point to silicate rocks having elevated $\mathrm{Rb} / \mathrm{Sr}$ ratios.

In addition to the $\mathrm{Sr}$ isotopes, $\mathrm{Pb}$ isotopes also stress the importance of interaction of the mineralizing fluid with silicate rocks (Fig. 8). The $\mathrm{Pb}$ isotope composition of sphalerite is very uniform, indicative of an isotopically wellhomogenized fluid system. It is more radiogenic than that of non-mineralized oolitic carbonate rock and of the residues of crystalline basement rocks. The only components, which are more radiogenic than the sphalerite residues are leachate and residue of marly limestone of Bathonian age and leachates of crystalline rocks (Fig. 8).

The oolitic limestone hosting a mineralized sample is more radiogenic than that from the non-mineralized level, which may indicate the interaction of mineralized rock with fluid containing a more radiogenic fraction of $\mathrm{Pb}$.

Possible candidates for the external fluid sources are (1) Middle Jurassic marl (Hauptrogenstein and Klingnau Formations, marly clay of the Aalenian Opalinuston Formation), (2) variegated continental claystone, intercalated with silt and sand of Late Triassic age, (3) Lower Triassic (Bundsandstein) red sandstone, conglomerate and mudstone, (4) Lower Permian red beds (Lower and Upper Rotliegendes), and (5) crystalline basement rocks, composed of granite and migmatitic gneiss.

The Middle Jurassic marl/marly limestone is not a likely source of ore fluid, because the mineralization was formed relatively shortly after the deposition of the sedimentary host rock, when the thickness of overlying sediments did not exceed $300 \mathrm{~m}$ (Gygi and Marchand 1982; Gygi and Persoz 1986). Therefore, the intraformational fluids could not attain high temperatures due to the small burial depth. Additionally, carbonate rocks tend to act as a buffer for hydrothermal fluids causing mineral precipitation through fluid neutralization, rather than liberating elements to fluids. Furthermore, as the marly formations are less permeable than sandstones, conglomerates, and fractured basement rocks, it is unlikely that important quantities of metals were leached from the Jurassic sedimentary rocks. If metals were remobilized from marls to adjacent carbonate layers during the compaction and diagenesis, one would expect to find sphalerite (or elevated metals concentrations in rocks) also in marl and limestone of Cretaceous age in the Jura Mountains. At present, there is, however, no evidence of base-metal mineralization or elevated $\mathrm{Zn}-\mathrm{Cd}-\mathrm{Pb}$ concentration in Cretaceous limestone of the Jura Mountains. Finally, the reducing environment in marl would prevent the transport of $\mathrm{Zn}$ and $\mathrm{Cd}$ by intraformational fluids.

We did not investigate the $\mathrm{Pb}$ isotope composition of Triassic detrital rocks, which were proposed as source 



Fig. $10{ }^{87} \mathrm{Sr} /{ }^{86} \mathrm{Sr}$ versus $1 /{ }^{86} \mathrm{Sr}$ (a) and $1 / \mathrm{Rb}$ versus ${ }^{87} \mathrm{Rb} /{ }^{86} \mathrm{Sr}$ (b) diagrams showing sphalerite residues (R). Arrows indicate the direction of elemental shifts

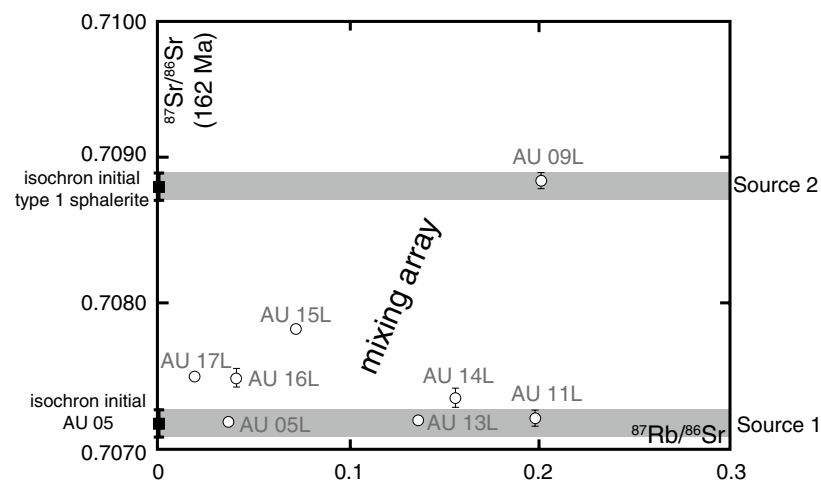

Fig. 11 Detailed ${ }^{87} \mathrm{Sr} /{ }^{86} \mathrm{Sr}$ versus ${ }^{87} \mathrm{Rb} /{ }^{86} \mathrm{Sr}$ diagram showing the isotope systematics of sphalerite inclusion fluids (L) and probable mixing trends between metal sources

rocks due to the elevated $\mathrm{Rb} / \mathrm{Sr}$ ratios of "source-2" fluids for sphalerite. However, the thickness of Upper Triassic detrital rocks does not exceed $40 \mathrm{~m}$ in the investigated area, and the thickness of detrital rocks of Early Triassic age is about 10-20 m (e.g., Riniken and Schafisheim boreholes; Thury et al. 1994). These horizons are therefore unlikely to have contributed significant amounts of metals to the mineralizing fluid.

The upward decrease in the concentration of secondary minerals from Triassic to Jurassic carbonates suggests that the fluids had a deep source, such as the basement rocks and/or Lower Permian red beds. Leaching of crystalline rocks was already proposed as a potential source of $\mathrm{Pb}$ and $\mathrm{Zn}$ in Mississippi Valley-type deposits (e.g., Chiaradia and Fontboté 2003). Leaching of crystalline rocks by hydrothermal fluids was qualitatively reproduced through laboratory experiments (see Chiaradia and Fontboté 2003 and references therein) using a variably strong and warm acid, and we performed this experiment for this study. Older crystalline rocks contain common $\mathrm{Pb}$ incorporated at the moment of their formation (magmatic crystallization or last metamorphic homogenization) plus radiogenic $\mathrm{Pb}$ developed in situ from the decay of $\mathrm{U}$ and Th. A moderately acidic, saline and hot fluid, probably responsible for the precipitation of sphalerite studied here (and more in general in MVT type deposits), will not be able to completely dissolve the silicate-bearing crystalline rock. It will mainly leach the radiogenic $\mathrm{Pb}$ fraction from crystal lattice defects created during the natural in situ decay of $U$ and $\mathrm{Th}$. Radiogenic $\mathrm{Pb}$ may also be preferentially located at intergranular sites from which it also is more easily extractable. The residual composition of crystalline rocks, after being stripped off of its radiogenic component, will approach the common lead fraction incorporated by the rock at the time of its formation (Chiaradia and Fontboté 2003). Consequently, the bulk rock fraction is expected to have a lead isotope composition intermediate between the residue and the leachate fractions.

In our study, the leachates of crystalline rocks were always more radiogenic than the corresponding residues (Fig. 8a), as expected from systematic measurements of Chiaradia and Fontboté (2003), and bulk granitic and metamorphic rocks from the southern Black Forest crystalline massif (Fig. 8b; Kober and Lippolt 1985) are intermediate between the residue and leachate fraction. The comparative $\mathrm{Pb}$ isotope patterns of sphalerite residues and crystalline rocks (Fig. 8) point to $\mathrm{Pb}$ sources located in basement rocks, which are similar to those exposed in the southern Black Forest farther north. However, input of metals from Permian red beds and the possibility of remobilization of sphalerite from mineralization located in Triassic carbonates and basement rocks cannot be ruled out.

Precipitation mechanism and control on sphalerite formation

The occurrence of well-crystallized, large (up to $3 \mathrm{~cm}$ ), sphalerite crystals filling dissolution cavities provides textural evidence for an epigenetic origin of the 
mineralization. The very uniform $\mathrm{Pb}$ isotope composition of sphalerite, indicating a well-homogenized fluid system, contrasts with very heterogeneous $\delta^{34} \mathrm{~S}$ values. This indicates a local source for reduced sulfur (Barnes 1997) and a common, regional, source for metal-bearing fluids. The isotope data suggest that sphalerite was precipitated as the result of the mixing of a metal-bearing brine and a local $\mathrm{H}_{2} \mathrm{~S}$-bearing fluid at the site of deposition. The oolitic limestones were more permeable than the surrounding marly formations at the time of ore formation, which favored the effective fluid mixing as a physical trap. The abundance of framboidal pyrite in the oolitic carbonate attests to the former presence of organic matter, which probably functioned as a chemical trap. Sphalerite precipitation often occurs at the interface between coarser-grained oolitic limestone (with higher permeability; Shepherd 1989) and finergrained oolitic limestone (with lower permeability; Fig. 3e, f). The existence of such permeability barriers and the association of sphalerite mineralization with fractures (Fig. 3d) indicates that coarser-grained oolitic limestone layers and faults may have acted as pathways and focusing systems for the mineralizing fluid.

A number of observations provides evidence for the small volume of hydrothermal fluids circulating in the Bajocian rocks and for the low metal content within the fluids (e.g., Barnes 1997): (1) slow crystallization of sphalerite, indicated by the development of large single crystals and absence of fine-grained ores; (2) rareness of mineralization in the studied oolitic carbonate rocks of Bajocian age combined with the significant dispersion of sphalerite mineralization over at least $100 \mathrm{~km}$ distance; (3) a lack of distinctive alteration features in the host rock related to hydrothermal fluid circulation; and (4) small difference in the $\mathrm{Sr}$ isotope composition of sphalerite residues and surrounding host rock. Indeed, as was discussed before, the initial ${ }^{87} \mathrm{Sr} /{ }^{86} \mathrm{Sr}$ ratio of 0.7088 reflected by the Type- 1 sphalerite isochron falls outside the range of marine ${ }^{87} \mathrm{Sr} /{ }^{86} \mathrm{Sr}$ signatures reported for Triassic and Jurassic carbonate rocks $\left({ }^{87} \mathrm{Sr} /{ }^{86} \mathrm{Sr}=0.70685-0.7083\right.$; McArthur et al. 2001). This indicates binary mixing of $\mathrm{Sr}$ mobilized from the carbonate host rocks and radiogenic $\mathrm{Sr}$ from external sources, which also provided $\mathrm{Rb}$. As this difference in the $\mathrm{Sr}$ isotope composition is not very large, it may reflect a low metal-bearing fluid to intraformational fluid (and host rock) ratio.

Metal contents of mineralizing fluids, their salinity, and temperature are difficult to estimate in the absence of thermometric and compositional studies of fluid inclusions in sphalerite. Rare primary fluid inclusions observed in the sphalerite samples, which were not located along fault planes or affected by necking down, were mostly allliquid (aqueous) even after attempts to nucleate bubbles, which implies the formation of sphalerite below $50{ }^{\circ} \mathrm{C}$ (Goldstein and Reynolds 1994). This temperature range may have resulted from the mixing of small amounts of relatively hot hydrothermal fluids with the low-temperature intraformational fluids, which could not attain higher temperatures due to the low burial depth of $<300 \mathrm{~m}$ (Gygi and Marchand 1982; Gygi and Persoz 1986) at the time of mineralization. Considering a normal geothermal gradient and the thickness of Triassic-Bajocian sediments of 500-600 $\mathrm{m}$ in the studied region (Thury et al. 1994), the temperature of fluids near the interface between the basement and Mesozoic sediments would not have exceeded $40-50{ }^{\circ} \mathrm{C}$. However, fluids of higher temperature may have circulated deeper in the fractured basement rocks and especially at the borders of thick (up to $5 \mathrm{~km}$; Thury et al. 1994) Permo-Carboniferous graben infills, along the deep-rooted rift-bounded faults. A highly fractured upper part of the basement, which is several hundred meters thick, was penetrated by several deep boreholes in northern Switzerland, and evidence for hydrothermal fluid circulation is provided by the extensive hydrothermal alteration of the rock in the immediate vicinity of water-conducting features, such as cataclastic zones, fractured zones with open joints, aplites and aplitic gneisses with brittle deformation (Thury et al. 1994). Fluid inclusion studies on calcite and quartz veins and pore-filling cements in these altered basement rocks indicate that hot (up to $140{ }^{\circ} \mathrm{C}$ ) saline fluids $\left(\mathrm{CaCl}_{2}-\mathrm{NaCl}-\mathrm{MgCl}_{2}\right)$ were present down to depths of more than $1,500 \mathrm{~m}$ between the Permian and Cenozoic (Mullis 1987). Saline fluids in the crystalline basement were at least partly of sedimentary origin and may have migrated from sedimentary rocks of Permo-Carboniferous and Triassic age (Thury et al. 1994). The existence of salt-containing evaporites in Triassic sediments may have resulted in important salinities of the formational fluid, which may have migrated downwards due to salinity (density) gradients. Metals were probably leached during the interaction of these brines with crystalline basement rocks or Permian red beds and were most probably transported as chloride complexes within brines upwards into the overlying sedimentary cover. The decrease in intensity and diversity of sulfide mineralizations from Permian to Jurassic rocks in the Jura Mountains may be related both to the precipitation of sulfides in permeable sedimentary strata containing reduced sulfur along the trajectory of the upward-moving hydrothermal fluids and to the progressive decrease in fluid temperature and its neutralization by carbonate rock, which led to a decrease in the metal transport capacity.

Hydrothermal, metal-transporting, fluids move from deeper to shallower regions along faults and through porous strata because of the presence of gradients in 
temperature, in situ stress and pore pressure, topographic relief, the effect of dilatational pumping (Muir Wood 1994; Sibson 1994), and other mechanisms. In the case of the Jura Mountains, basement faults were reactivated during the Mesozoic and propagated into the younger sedimentary cover, despite their partial dissipation by Triassic evaporates. These active faults allowed for the ascent and circulation of hydrothermal fluids in the Mesozoic sedimentary rocks. The disseminated character of sphalerite mineralization and its important spatial distribution imply not only low metal concentrations in the fluid, but also its disseminated flow. The absence of important fluid focusing may indicate the existence of rather rare, dispersed fault systems, likely formed during episodic paleoseismic ruptures, which were active during a limited period of time.

Therefore, the main controls of sphalerite precipitation in the Bajocian oolitic carbonate rocks were (1) carbonate lithology (oolitic limestone), which defined permeability of the host rock and provided suitable conditions for the effective mixing of warm metal-bearing fluids with cold, intraformational, reducing fluids; (2) availability of reduced sulfur in the form of early diagenetic pyrite and organic sulfur compounds; and (3) existence of deeprooted faults allowing the transport of saline metal-bearing solutions from the deeper strata/basement into the overlying sediments.

Timing of sphalerite precipitation and Mesozoic tectonic activity in Europe

Multiple reactivation phases of deeply rooted faults and associated hydrothermal events during the Mesozoic and especially during the Triassic-Jurassic were documented for various hydrothermal ore deposits, which are hosted in the Hercynian basement and overlying Triassic Buntsandstein deposits in the Black Forest Massif, SW Germany (Bonhomme et al. 1983; Brockamp et al. 1994; Wetzel et al. 2003; Pfaff et al. 2009; Romer et al. 2010). The numerous radiometric ages determined for these deposits indicate distinct maxima in hydrothermal activity at 230, 210, 190, and $170 \mathrm{Ma}$ (Romer et al. 2010; 664 ages of hydrothermal mineralizations compilated). Romer et al. (2010), however, agree that their geochronologic database does not reflect the relative importance of the identified hydrothermal events, and less important events tend to be overrepresented relative to the few major events.

The isochron model age for the formation of the herestudied sphalerite samples of approximately $162 \pm 4.1$ or 2.8 Ma (Callovian-Late Oxfordian; Gradstein et al. 2012) corresponds to a phase of important spreading of the
Alpine Tethys and Central Atlantic oceans, and of thermal and increased tectonic subsidence in the areas flanking the Alpine Tethys (Fig. 1c; Stampfli and Borel 2002). Seafloor spreading was exceptionally intense during the Late Callovian and Oxfordian (Corbin et al. 2000; Cogne and Humler 2004). Numerical modeling by Bird et al. (2007) indicates that in the Central Atlantic eastwarddirected ridge jumps occurred at $170 \mathrm{Ma}$ and westwarddirected ridge jumps occurred between 164 and $159 \mathrm{Ma}$. Labails et al. (2010) do not support this hypothesis and propose a change in the direction of relative plate motion and an increase in spreading rate during these periods. Whereas the existence or not of ridge jumps between 164 and $159 \mathrm{Ma}$ is questionable, it is evident that large-scale tectonic movements were important in the whole central Atlantic region during this period and that tectonic stress may have affected the European region. Romer et al. (2010) also noted that Mesozoic mineralization appears to be related to changes in the stress pattern at the margins of continental Europe, as plate separation and crustal relaxation occurred in the Central Atlantic-Tethys region at approximately 166-160 Ma.

In the southern Upper Rhine Graben area, from the study of zircon fission tracks on basement samples, Timar-Geng et al. (2004) derived a wide spectrum of ages ranging from $247 \pm 22$ to $162 \pm 14$ Ma for the phase of thermal overprint related to hydrothermal fluid migration. In the southeastern French Basin, a phase of marked subsidence related to post-rift thermal activity and corresponding high depositional rates started from Late Bathonian times onwards (Pienkowski et al. 2008). In the northeastern part of the Swiss Jura Mountains, the most important phases of enhanced subsidence and associated reactivation of Paleozoic basement faults occurred during the Sinemurian/Pliensbachian/Toarcian, Aalenian, Bajocian/Bathonian, and Oxfordian (Trümpy 1980; Wetzel et al. 2003).

Evidence of increased tectonic and hydrothermal activity in the Tethyan realm during the Jurassic and Early Cretaceous periods, related to the opening of Atlantic realm and spreading of the Alpine Tethys (and related mineralization), was mentioned in numerous studies performed on base-metal mineralization and/or carbonate diagenesis/ cement stratigraphy in Europe and Northern Africa (e.g., Bonhomme et al. 1983; Zeeh et al. 1997; Kappler and Zeeh 2000; Heijlen et al. 2001, 2003; Kuhlemann et al. 2001; Makhoukhi et al. 2003; Muchez et al. 2005; Pfaff et al. 2009; Romer et al. 2010; Brockamp et al. 2011). However, mineralization in the Jura Mountains (and associated high concentrations of $\mathrm{Zn}$ and $\mathrm{Cd}$ in carbonate rocks) was found only in rocks of Triassic-Late Jurassic age. No evidence of base-metal mineralization/elevated concentrations of $\mathrm{Zn}$, 
Cd in carbonate rocks of Cretaceous age were described at present to our knowledge.

All by all, the Callovian-Late Oxfordian age of sphalerite mineralization within Bajocian oolitic limestone in the Jura Mountains appears to be geologically plausible.

\section{Geological implications}

In the Jura Mountains, the existence of sphalerite mineralization in younger rocks of Late Oxfordian age (Jacquat et al. 2011) demonstrates that fluid introduction into the carbonate rocks was episodic and that the hydrothermal system continued to be active following the phase of sphalerite precipitation during the Callovian-Late Oxfordian. Hydrothermal alteration and mineralization in the southern Black Forest crystalline massif, in the vicinity of study area, occurred episodically over the last $300 \mathrm{Ma}$ with distinct peaks around $300 \mathrm{Ma}$ (late Variscan), several episodes between 200 and $100 \mathrm{Ma}$ (possible related to the opening of the Atlantic Ocean in the Jurassic and Early Cretaceous), and around 40-20 Ma (related to the opening of the Rhine Graben) (Pfaff et al. 2009; and references therein). Therefore, considering the existence of hydrothermal activity during the Cenozoic in the area proximal to the northeastern part of Jura Mountains, the hypothesis that a part of the sphalerite mineralization in the study area may have been formed during tectonic activity related to the opening of the Rhine Graben during the Oligocene cannot be ruled out. This is also supported by the petrographic observation that sphalerite does not only occur in diagenetic cavities but also in late fractures cross-cutting the rock.

This implies that the mineralization in the Jura Mountains may have formed during multiple episodes, and the existence of mineralization at the same place in rocks of different age may indicate the existence of basement structures, which are most prone to reactivation. Reactivation of distinct basement structures may have depended on the orientation of the stress field. Faults limiting the PermoCarboniferous graben structures are probably the most important tectonic features in the basement of northern Switzerland. We propose that these Variscan faults were reactivated episodically in an oblique divergent sense during paleoseismic events. The vertical movement of hydrothermal fluids from the basement into the overlying sedimentary may have occurred along these transtensional faults. The Triassic salt-containing evaporite layers may have facilitated the sealing of fractures and faults, which cut through these formations following paleoseismic events, thereby deleting the evidence of the coupling between basement and its Mesozoic cover by faults. As the active basement faults are partly spatially related to the borders of the Permo-Carboniferous graben structures, the position of sphalerite mineralization may be used for the prediction of these basement structures, in addition to facies changes in the sedimentary cover (Wetzel et al. 2003).

Therefore, we propose that the presence of sphalerite mineralization directly records the reactivation of the Variscan basement structures and activity of transtensional faults in the Jura Mountains during a phase of pronounced extension in the Middle-Late Jurassic, associated with thermal and/or tectonic subsidence in the basinal area. Thickskinned tectonics exists probably not only today (Molliex et al. 2011) but was also episodically effective during the Mesozoic era.

\section{Conclusions}

A combination of petrographic and geochemical techniques was applied to better constrain the origin and evolution of the fluid systems responsible for the formation of sphalerite mineralization in the northeastern part of the Jura Mountains, Switzerland. The shallow-marine environment, which prevailed in the area of the future Jura Mountains during the Bajocian, favored the deposition of thick, highly permeable, oolitic carbonate and marl. As a consequence of intensified extensional tectonics, related to the spreading of the Central Atlantic and Alpine Tethys oceans, saline metal-bearing fluids from deeper strata were expelled into permeable Bajocian carbonates along deeply penetrating, reactivated, fault structures of Paleozoic origin. The incoming metal-rich fluids were mixed with local fluids containing biogenic sulfide, thus promoting the precipitation of sphalerite.

Sphalerites in carbonate rocks of Jurassic age in several locations in the Jura Mountains represent the same style of mineralization. Therefore, the proposed mechanism of mineralization and precipitation by mixing may be similar for the entire Jura Mountains.

$\mathrm{Rb}-\mathrm{Sr}$ age dating points to sphalerite formation near the Middle-Late Jurassic boundary, at approximately $162 \mathrm{Ma}$. Further mineralization may have formed later, for example, during the Alpine orogeny associated with the deformation of the foreland and opening of the Rhine Graben during the Cenozoic (Oligocene), similarly to the mineralization events in the southern Black Forest Massif.

It appears that isolated sphalerite occurrences in marly lenses (Type 1) can be successfully dated, as the $\mathrm{Rb}-\mathrm{Sr}$ system in the sphalerite lattice remained unaffected by later disturbances, most likely due to a protective sealing effect provided by the impermeability of the marl. Conversely, fracture-hosted sphalerite associated with sparry carbonates 
(Type 2) shows significant $\mathrm{Rb}-\mathrm{Sr}$ elemental and isotopic shifts, including drastic depletion in both $\mathrm{Rb}$ and $\mathrm{Sr}$. This "chemical cleaning" most likely occurred in the course of younger recrystallization and/or remobilization-reprecipitation processes, rendering these sphalerites unsuitable for $\mathrm{Rb}-\mathrm{Sr}$ dating. The analysis of sphalerite fluid inclusions points to the presence of primary and secondary fluids of different origin. $\mathrm{Rb}-\mathrm{Sr}$ systematics indicate two distinct fluid sources, one intraformational source located in the carbonate host rocks to mineralization and one external reservoir which can be identified as the silicate rock (crystalline basement).

Our study provides the first direct age determination of sediment-hosted mineralization in the Mesozoic sedimentary cover of the Jura Mountain area. It furthermore demonstrates that the circulation of metal-bearing, deeply sourced, hydrothermal fluids affected the carbonate rocks of Bajocian age, and furnishes direct evidence for tectonic activity in the Jura Mountains during the late Middle-early Late Jurassic. The study also confirms the existence of reactivated basement faults in response to Jurassic tectonic activity.

$\mathrm{Zn}$ and $\mathrm{Cd}$ incorporation into the Bajocian carbonate rock occurred during the circulation of mineralizing hydrothermal fluids, and possibly later, during the oxidation of preexisting sulfide minerals. The presence of sphalerite mineralization and associated geochemical anomalies in $\mathrm{Zn}$ and $\mathrm{Cd}$ contents in carbonate rocks may be used to trace basement features. This study confirms the importance of widespread hydrothermal activity in the southern European and Alpine Tethys area during the Mesozoic period.

Acknowledgments This research would not have been possible without the help of Hans Holenweg and Rolf Hirt, who collected and generously provided all sphalerite samples investigated here. Their help and advice are greatly acknowledged. We are also grateful to Angelika Kalt, Olivier Jacquat, Lluis Fontboté, Robert Moritz, Beda Hofmann, Torsten Vennemann, Stefan Schmalholz, and Gérard Stampfli for their advise and experience. Thin sections and polished samples were kindly provided by André Villard. We gratefully acknowledge financial support from the Universities of Neuchâtel, Lausanne, Geneva, the CUSO-supported doctoral program in mineral sciences, and the Geonova project. Finally, we thank the reviewers (anonymous and Beda Hofmann) for their detailed and constructive comments, which helped to substantially improve the manuscript.

\section{Appendix}

See Tables 4 and 5. 


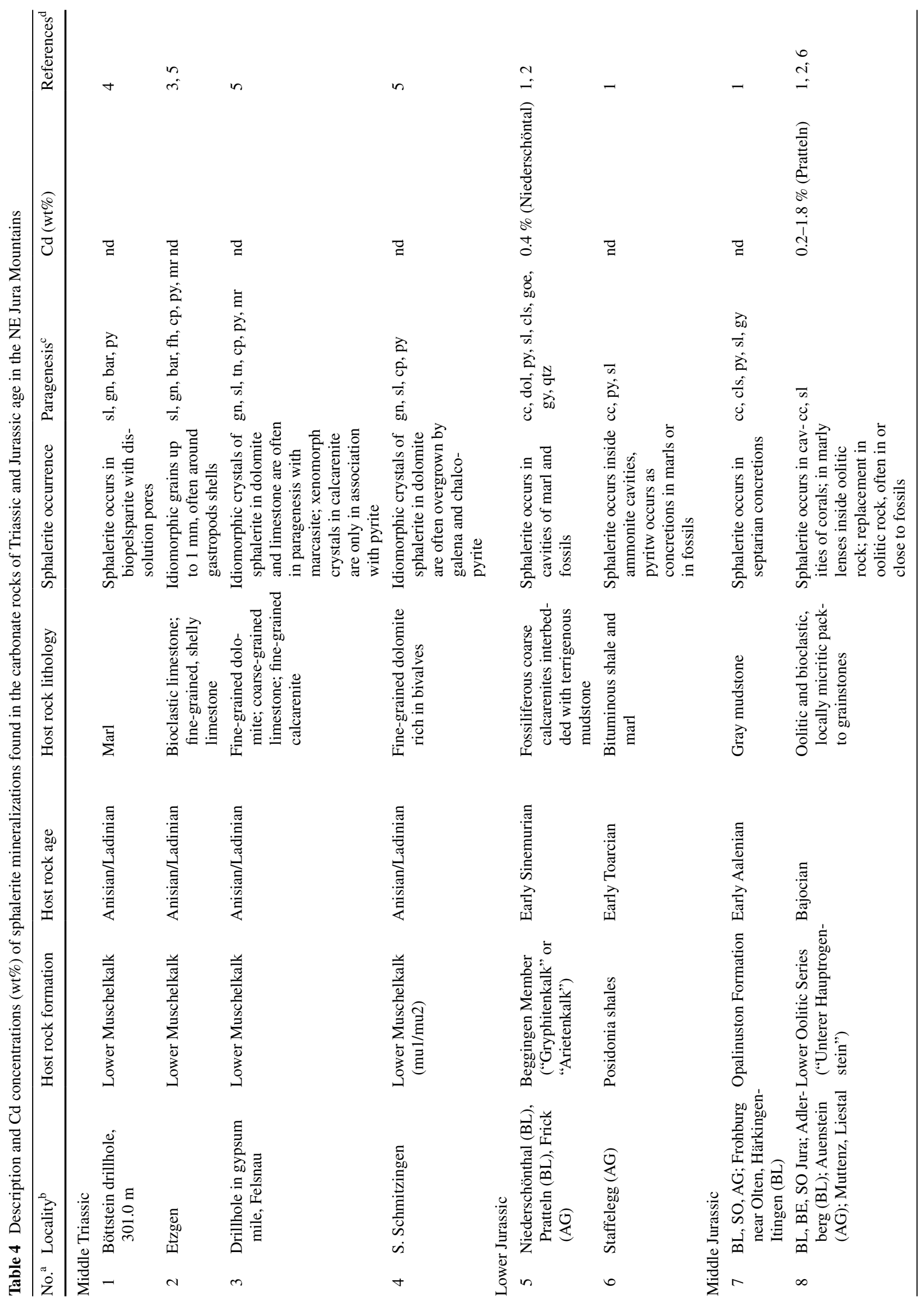




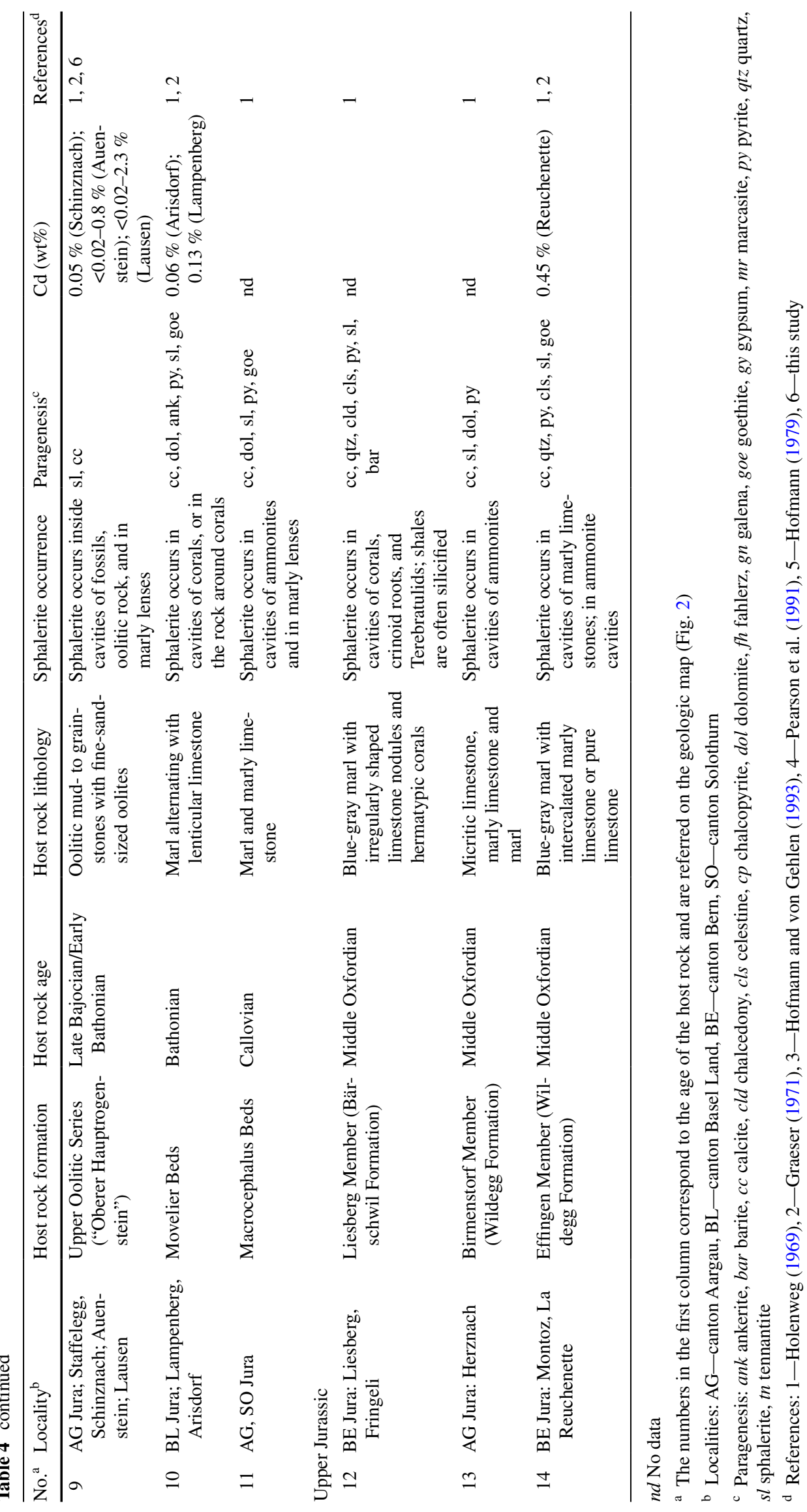


Table 5 Descriptions of samples analyzed for $\mathrm{Pb}$ and $\mathrm{Sr}$ isotopes

\begin{tabular}{|c|c|c|}
\hline Sample & Locality & Description \\
\hline \multicolumn{3}{|c|}{ Samples from NE Jura Mountains, NW Switzerland } \\
\hline AUN 0 & Auenstein & Ooid limestone from non-mineralized horizon (Upper Bajocian age) \\
\hline $\mathrm{AU} 4 \mathrm{r}$ & Auenstein & Ooid limestone from mineralized horizon (Upper Bajocian age) \\
\hline HDB 38 & Holderbank & Marly limestone (Upper Bajocian age) \\
\hline \multicolumn{3}{|c|}{ Samples from southern Black Forest Massif, SW Germany and NW Switzerland } \\
\hline $\mathrm{Pb} 5034$ & Zipfelhof & Biotite gneiss \\
\hline $\mathrm{Pb} 5035$ & Albtal & Biotite granite with big alkali feldspars \\
\hline $\mathrm{Pb} 5036$ & Todtmoos & Leucocratic gneiss \\
\hline Pb5037 & Laufenburg & Migmatitic gneiss \\
\hline $\mathrm{Pb} 5038$ & Laufenburg & Migmatitic gneiss \\
\hline
\end{tabular}

\section{References}

Allenbach RP (2002) The ups and downs of "Tectonic Quiescence"recognizing differential subsidence in the epicontinental sea of the Oxfordian in the Swiss Jura Mountains. Sediment Geol 150:323-342

Allenbach RP, Wetzel A (2006) Spatial patterns of Mesozoic facies relationships and the age of the Rhenish Lineament: a compilation. Int J Earth Sci 95:803-813

Barnes HL (1997) Geochemistry of hydrothermal ore deposits, 3rd edn. Wiley, New York, p 992. ISBN: 978-0-471-57144-5

Benitez-Vasquez N (1999) Cadmium speciation and phyto-availability in soils of the Swiss Jura: hypothesis about its dynamic. Ph.D. thesis, Ecole Polytechnique Fédérale de Lausanne, Switzerland

Birck JL (1986) Precision K-Rb-Sr isotopic analyses: application to $\mathrm{Rb}-\mathrm{Sr}$ chronology. Chem Geol 56:73-88

Bird DE, Hall SA, Burke K, Casey JF, Sawyer DS (2007) Early central Atlantic Ocean seafloor spreading history. Geosphere 3(5):282-298

Bonhomme MG, Bühmann D, Besnus Y (1983) Reliability of K/Ardating of clays and silifications associated with vein mineralizations in Western Europe. Geol Rundsch 72:105-117

Brockamp O, Zuther M, Clauer N (1994) K-Ar dating of episodic Mesozoic fluid migrations along the fault system of Gernsbach between the Moldanubian and Saxothuringian (Northern Black Forest, Germany). Geol Rundsch 83(1):180-185

Brockamp O, Schlegel A, Clauer N (2011) Mesozoic hydrothermal impact on Rotliegende and Bunter immature sandstones of the High Rhine trough and its adjacent eastern area (southern Black Forest, Germany). Sedim Geol 234:76-88

Chiaradia M, Fontboté L (2003) Separate lead isotope analyses of leachate and residue rock fractions: implications for metal tracing in ore deposit studies. Miner Depos 38:185-195

Christensen JN, Halliday AN, Vearncombe JR, Kesler SE (1995a) Testing models of large-scale crustal fluid flow using direct dating of sulfides: $\mathrm{Rb}-\mathrm{Sr}$ evidence for early dewatering and formation of Mississippi Valley-type deposits, Canning Basin, Australia. Econ Geol 90:877-884

Christensen JN, Halliday AN, Leigh KE, Randell RN, Kesler SE (1995b) Direct dating of sulfides by Rb-Sr: a critical test using the Polaris Mississippi Valley-type $\mathrm{Zn}-\mathrm{Pb}$ deposit. Geochim Cosmochim Acta 59:5191-5197

Cogne J-P, Humler E (2004) Temporal variation of oceanic spreading and crustal production rates during the last $180 \mathrm{My}$. Earth Planet Sci Lett 227:427-439

Cook NJ, Ciobanu CL, Pring A, Skinner W, Schimizu M, Danyushevsky L, Saini-Eidukat B, Melcher F (2009) Trace and minor elements in sphalérite: a LA-ICPMS study. Geochim Cosmochim Acta 73:4761-4791
Corbin JC, Person A, Iatzoura A, Ferre B, Renard M (2000) Manganese in pelagic carbonates, indication of major tectonic events during the geodynamic evolution of a passive continental margin (the Jurassic European margin of the Tethys-Ligurian Sea). Palaeogeogr Palaeocl 156:123-138

Deniel C, Pin C (2001) Single-stage method for the simultaneous isolation of lead and strontium from silicate samples for isotopic measurements. Anal Chim Acta 426:95-103

Dubois JP, Benitez N, Liebig T, Baudraz M, Okopnik F (2002) Le cadmium dans les sols du haut Jura Suisse. In: Baize D, Tercé M (eds) Les élements traces métalliques dans les sols-Approches fonctionnelles et spatiales. INRA Editions, Paris, pp 33-52

Efimenko N, Matera V, Adatte T, Föllmi KB (2008) Cadmium anomalies in Jurassic carbonates in western and southern Europe: towards the causes and mechanisms. Geophys Res Abstr 10:A09829 (abstr.)

Fowler AD, L'Heureux I (1996) Self-organized banded sphalerite and branching galena in the Pine Point ore deposit-Northwest Territories. Can Mineral 34:1211-1222

Goldstein RH, Reynolds TJ (1994) Systematics of fluid inclusions in diagenetic minerals: SEPM short course, vol 31. Society for Sedimentary Geology, Tulsa, USA, p 199

Gong H, Rose AW, Suhr NH (1977) The geochemistry of cadmium in some sedimentary rocks. Geochim Cosmochim Acta 41:1687-1692

Gonzalez R (1996) Response of shallow-marine carbonate facies to third-order and high-frequency sea-level fluctuations: Hauptrogenstein Formation, northern Switzerland. Sediment Geol 102:111-130

Gonzalez R, Wetzel A (1996) Stratigraphy and paleogeography of the Hauptrogenstein and Klingnau Formations (middle Bajocian to late Bathonian), northern Switzerland. Eclogae Geol Helv 89:695-720

Gradstein FM, Ogg JC, Schmitz M, Ogg G (eds) (2012) The geologic times scale 2012, 1 and 2 edn. Elsevier, Amsterdam, p 1444

Graeser S (1971) Mineralogisch-geochemische Untersuchungen an Bleiglanz und Zinkblende. Schweiz Mineral Petrogr Mitt 51:414-442

Gygi RA, Marchand D (1982) Les faunes de Cardioceratinae (Ammonoidea) du Callovien terminal et de l'Oxfordien inferieur et moyen (Jurassique) de la Suisse septentrionale; stratigraphie, paleoecologie, taxonomie preliminaire. Geobios 15:517-571

Gygi RA, Persoz F (1986) Mineralostratigraphy, litho- and bio-stratigraphy combined in correlation of the Oxfordian (Late Jurassic) formations of the Swiss Jura Range. Eclogae Geol Helv 79:385-454

Heijlen W, Muchez Ph, Banks DA (2001) Origin and evolution of high-salinity, $\mathrm{Zn}-\mathrm{Pb}$ mineralising fluids in the Variscides of Belgium. Miner Depos 36:165-176 
Heijlen W, Muchez P, Banks DA, Schneider J, Kucha H, Keppens E (2003) Carbonate-hosted $\mathrm{Zn}-\mathrm{Pb}$ deposits in Upper Silesia, Poland: origin and evolution of mineralizing fluids and constraints on genetic models. Econ Geol 98(5):911-932

Heinrichs H, Schulz-Dobrick B, Wedepohl KL (1980) Terrestrial geochemistry of $\mathrm{Cd}, \mathrm{Bi}, \mathrm{Tl}, \mathrm{Pb}, \mathrm{Zn}$ and $\mathrm{Rb}$. Geochim Cosmochim Acta 44:1519-1533

Herlec U, Spangenberg JE, Lavric JV (2010) Sulfur isotope variations from orebody to hand-specimen scale at the Mezica leadzinc deposit, Slovenia: a predominantly biogenic pattern. Miner Depos 45(6):531-547

Hofmann B (1979) Blei-, Zink-, Kupfer- und Arsenvererzungen im Wellengebirge (unterer Muschelkalk, Trias) am südlichen und östlichen Schwarzwaldrand. Sonderdruck aus den Mitteilungen der Naturforschenden Gesellschaft Schaffhausen Band XXXI, Jahrgang 1978/80. Buchdruckerei Kühn, Schaffhausen

Hofmann B (1989) Erzmineralien in paläozoischen, mesozoischen und tertiären Sedimenten der Nordschweiz und Südwestdeutschlands. Schweiz Mineral Petrogr Mitt 69:345-357

Hofmann BA, von Gehlen K (1993) Formation of stratiform sulfide mineralizations in the Lower Muschelkalk (Middle Triassic) of Southwestern Germany and Northern Switzerland: constraints from sulfur isotope data. Schweiz Mineral Petrogr Mitt 73:365-374

Holenweg H (1968) Zinkblende im Schweizer Jura. Urner Mineralienfreund 6:25-28

Holenweg H (1969) Mineralparagenesen im Schweizer Jura. Schweiz Strahler 3:303-308

Holenweg H, Offermann E (1977) Mineralfunde in Fossilhohlräume aus dem Schweizer Jura. Der Aufschluss 28:205-218

Homberg C, Bergerat F, Philippe Y, Lacombe O, Angelier J (2002) Structural inheritance and Cenozoic stress fields in the Jura foldand-thrust belt (France). Tectonophysics 357:137-158

Jacquat O, Voegelin A, Juillot F, Kretzschmar R (2009) Changes in Zn speciation during soil formation from $\mathrm{Zn}$-rich limestones. Geochim Cosmochim Acta 73:5554-5571

Jacquat O, Rambeau C, Voegelin A, Efimenko N, Villard A, Föllmi K, Kretzschmar R (2011) Origin of high Zn contents in Jurassic limestone of the Jura mountain range and the Burgundy: evidence from Zn speciation and distribution. Swiss J Geosci 104:409-424

Jank M (2004) New insights into the development of the Late Jurassic Reuchenette formation of NW Switzerland (Late Oxfordian to Late Kimmeridgian, Jura Mountains). Ph.D. thesis, Basel University, Switzerland

Jank M, Meyer CA, Wetzel A (2006) Late Oxfordian to Late Kimmeridgian carbonate deposits of NW Switzerland (Swiss Jura): stratigraphical and palaeogeographical implications in the transition area between the Paris Basin and the Tethys. Sediment Geol 186:237-263

Jones CE, Jenkyns HC, Hesselbo SP (1994) Strontium isotopes in Early Jurassic seawater. Geochim Cosmochim Acta 58:1285-1301

Kampschulte A, Strauss H (2004) The sulfur isotopic evolution of Phanerozoic seawater based on the analysis of structural substituted sulfate in carbonates. Chem Geol 204:255-286

Kappler P, Zeeh S (2000) Relationship between fluid flow and faulting in the Alpine realm (Austria, Germany, Italy). Sediment Geol 131(3):147-162

Kober B, Lippolt HJ (1985) Pre-Hercynian mantle lead transfer to basement rocks as indicated by lead isotopes of the Schwarzwald crystalline, SW-Germany. I. The lead isotope distribution and its correlation. Contrib Mineral Petrol 90:162-171

Kossmat F (1927) Gliederung des varistischen Gebirgsbaues. Abh Sächs Geol L-A 1:1-39

Kuhlemann J, Vennemann T, Herlec U, Zeeh S, Bechstädt T (2001) Variations of sulfur isotopes, trace element compositions, and cathodoluminescence of Mississippi Valley-type $\mathrm{Pb}-\mathrm{Zn}$ ores from the Drau Range, eastern Alps (Slovenia-Austria): implications for ore deposition on a regional versus microscale. Econ Geol 96(8):1931-1941

Labails C, Olivet JL, Aslanian D, Roest WR (2010) An alternative early opening scenario for the Central Atlantic Ocean. Earth Planet Sci Lett 297(3):355-368

Laubscher H (1965) Ein kinematisches Modell der Jurafaltung. Eclogae Geol Helv 58:231-318

Ludwig KR (1980) Calculation of uncertainties of $\mathrm{U}-\mathrm{Pb}$ isotope data. Earth Planet Sci Lett 46:212-220

Ludwig KR (2003) User's manual for Isoplot/Ex version 3.00: a geochronological toolkit for Microsoft Excel. Berkeley Geochronology Center Spec. Publ., Berkeley, USA, p 4

Machel HG, Krouse HR, Sassen R (1995) Products and distinguishing criteria of bacterial and thermochemical sulfate reduction. Appl Geochem 10(4):373-389

Makhoukhi S, Marignac Ch, Pironon J, Schmitt JM, Marrakchi C, Bouabdelli M, Bastoul A (2003) Aqueous and hydrocarbon inclusions in dolomite from Touissit-Bou Beker district, Eastern Morocco: a Jurassic carbonate hosted $\mathrm{Pb}-\mathrm{Zn}-(\mathrm{Cu})$ deposit. J Geochem Explor 78-79:545-551

Matter A, Peters T, Bläsi H-R, Meyer J, Ischi H, Meyer Ch (1988) Sondierbohrung Weiach-Geologie. NAGRA Technischer, Bericht 86

McArthur JM, Howarth RJ, Bailey TR (2001) Strontium isotope stratigraphy: LOWESS version 3: best-fit to the marine Sr-isotope curve for 0-509 Ma and accompanying look-up table for deriving numerical age. J Geol 109:155-170

Molliex S, Fabbri O, Bichet V, Madritsch H (2011) Possible Quaternary growth of a hidden anticline at the front of the Jura foldand-thrust belt: geomorphological constraints from the Forêt de Chaux area, France. Bull Soc Geol Fr 182(4):337-346

Muchez P, Heijlen W, Banks D, Blundell D, Boni M, Grandia F (2005) 7: extensional tectonics and the timing and formation of basin-hosted deposits in Europe. Ore Geol Rev 27(1):241-267

Muir Wood R (1994) Earthquakes, strain-cycling and the mobilization of fluids. In: Parnell J (ed) Geofluids: origin, migration, and evolution of fluids in sedimentary basins, vol 78. Geological Society Spec. Publ., Oxford, UK, pp 85-98

Mullis J (1987) Fluideinschluss-Untersuchungen in den NagraBohrungen der Nordschweiz. Eclogae Geol Helv 80:553-568

Nelson J, Paradis S, Christensen J, Gabites J (2002) Canadian Cordilleran Mississippi Valley-type deposits: a case for Devonian-Mississippian back-arc hydrothermal origin. Econ Geol 97:1013-1036

Ohmoto H, Goldhaber MB (1997) Sulfur and carbon isotopes. In: Barnes HL (ed) Geochemistry of hydrothermal ore deposits, 3rd edn. Wiley, New York, pp 517-611

Ohmoto H, Rye RO (1979) Isotopes of sulfur and carbon. In: Barnes HL (ed) Geochemistry of hydrothermal ore deposits, 2nd edn. John Wiley \& Sons, New York, pp 509-567

Peters T (1987) Das Kristallin der Nordschweiz: Petrographie und hydrothermale Umwandlungen. Eclogae Geol Helv 80:305-322

Pearson FJ, Balderer W, Loosli HH, Lehmann BE, Matter A, Peters, TJ, Schmassmann H, Gautschi A (1991) Applied isotope hydrogeology. A case study in northern Switzerland. Studies in environmental science, vol 43. Elsevier, Amsterdam

Pettke T, Diamond LW (1996) Rb-Sr dating of sphalerite based on fluid inclusion-host mineral isochrons: a clarification of why it works. Econ Geol 91:951-956

Pfaff K, Romer RL, Markl G (2009) U-Pb ages of ferberite, chalcedony, agate, 'U-mica' and pitchblende: constraints on the mineralization history of the Schwarzwald ore district. Eur J Mineral 21:817-836 
Pienkowski G, Schudack ME et al (2008) Jurassic. In: McCann T (ed) The geology of Central Europe. Mesozoic and Cenozoic, vol 2. Geological Society, London, pp 823-922

Pittet B (1996) Contrôles climatiques, eustatiques et tectoniques sur des systèmes mixtes carbonates-siliciclastiques de plate-forme: exemples de l'Oxfordien (Jura Suisse, Normandie, Espagne). Ph.D. thesis, Fribourg University, Switzerland

Prudente D (1999) Distribution des teneurs naturelles en cadmium dans les sols de la forêt communale des Fourgs (Doubs, France). Ph.D. thesis, Ecole Polytechnique Fédérale de Lausanne, Switzerland

Quesne D, Guiraud M, Garcia J-P, Thierry J, Lathuilière B, Audebert N (2000) Marqueurs d'une structuration extensive jurassique en arrière de la marge nord-téthysienne (Monts du Mâconnais, Bourgogne, France). C R Acad Sci IIA 330:623-629

Quezada-Hinojosa R, Matera V, Adatte T, Rambeau CMC, Föllmi KB (2009) Cadmium distribution in soils covering Jurassic oolitic limestone with high $\mathrm{Cd}$ contents in the Swiss Jura. Geoderma 150:287-301

Rambeau CMC (2006) Cadmium anomalies in Jurassic carbonates (Bajocian, Oxfordian) in western and southern Europe. Ph.D. thesis, Neuchâtel University, Switzerland

Rambeau CMC, Baize D, Saby N, Matera V, Adatte T, Föllmi KB (2010) High cadmium concentrations in Jurassic limestone as the cause for elevated cadmium levels in deriving soils: a case study in Lower Burgundy. Earth Sci Environ. doi:10.1007/ s12665-010-0471-0

Romer RL, Schneider JC, Linnemann U (2010) Post-Variscan deformation and hydrothermal mineralization in Saxo-Thuringia and beyond: a geochronological review. In: Linnemann U, Romer RL (eds) Pre-mesozoic geology of Saxo-Thuringia. Schweizerbart Science, Stuttgart, Germany, pp 347-362

Schaltegger U, Zwingmann H, Clauer N, Larqué Ph, Stille P (1995) $\mathrm{K}-\mathrm{Ar}$ dating of a Mesozoic hydrothermal activity in Carboniferous to Triassic clay minerals of northern Switzerland. Schweiz Mineral Petrogr Mitt 75:163-176

Shepherd RG (1989) Correlations of permeability and grain size. Groundwater 27(5):633-638

Sibson RH (1994) Crustal stress, faulting, and fluid flow. In: Parnell J (ed) Geofluids: origin, migration, and evolution of fluids in sedimentary basins, vol 78. Geological Society Spec. Publ., Oxford, UK, pp 69-84

Stampfli GM, Borel GD (2002) A plate tectonic model for the Paleozoic and Mesozoic constrained by dynamic plate boundaries and restored synthetic oceanic isochrons. Earth Planet Sci Lett 19:17-33

Strauss H (1997) The isotopic composition of sedimentary sulfur through time. Palaeogeogr Palaeoecol 132:97-118

Strauss H (1999) Geological evolution from isotope proxy signalssulfur. Chem Geol 161:89-101

Tectonic Map of Switzerland 1:500 000 (2005) Compiled by: Geological Institute, University of Bern, and Federal Office for Water und Geology. ISBN: 3-906723-56-9

Thierry J, Barrier E (2000) Middle Callovian, map 9. Atlas PeriTethys, palaeogeographical maps: explanatory notes. Commission de la Carte Géologique du Monde, Paris, pp 49-110
Thury M, Gautschi A, Mazurek M, Müller WH, Naef H, Pearson FJ, Vomvoris S, Wilson W (1994) Geology and hydrogeology of the crystalline basement of Northern Switzerland-synthesis of regional investigations 1981-1993 within the Nagra radioactive waste disposal programme. Nagra technical report series, NTB 93-01. Nagra, Wettingen

Timar-Geng Z, Fügenschuh B, Schaltegger U, Wetzel A (2004) The impact of the Jurassic hydrothermal activity on zircon fission track data from the southern Upper Rhine Graben area. Schweiz Mineral Petrogr Mitt 84:257-269

Todt W, Cliff RA, Hanser A, Hofmann AW (1996) Evaluation of a ${ }^{202} \mathrm{~Pb}-{ }^{205} \mathrm{~Pb}$ double spike for high-precision lead isotope analysis. In: Basu A, Hart SR (eds) Earth processes: reading the isotopic code, vol 95. American Geophysical Union Geophysical Monograph, Washington, USA, pp 429-437

Trümpy R (1980) An outline of the geology of Switzerland, 1st edn. Wepf, Basel

Védrine S, Strasser A (2009) High-frequency palaeoenvironmental changes on a shallow carbonate platform during a marine transgression (Late Oxfordian, Swiss Jura Mountains). Swiss J Geosci 102:247-270

Veuve P (2000) Etude géochimique et sédimentaire d'un enrichissement en cadmium observe dans les calcaires oolitiques jurassiques du Jura. Diploma thesis, Neuchâtel University, Switzerland

Wendt I, Carl C (1991) The statistical distribution of the mean squared weighted deviation. Chem Geol 86:275-285

Wetzel A, Allia V (2000) The significance of hiatus beds in shallowwater mudstones: an example from the Middle Jurassic of Switzerland. J Sediment Res 70:170-180

Wetzel A, Allia V (2003) Der Opalinuston in der Nordschweiz: Lithologie und Ablagerungsgeschichte. Eclogae Geol Helv 96:451-469

Wetzel A, Allenbach R, Allia V (2003) Reactivated basement structures affecting the sedimentary facies in a tectonically "quiescent" epicontinental basin; an example from NW Switzerland. Sediment Geol 157:153-172

Zartman RE, Doe BR (1981) Plumbotectonics-the model. Tectonophysics 75:135-162

Zeeh S, Walter U, Kuhlemann J, Herlec U, Keppens E, Bechstädt T (1997) Cement stratigraphy as a tool for fluid flow reconstruction: a study in parts of the Eastern Alps (Austria, Germany, Slovenia). In: Montanez IP, Gregg J, Shelton KL (eds) Basin-wide diagenetic patterns: integrated petrologic, geochemical, and hydrologic considerations, vol 57. Soc. Econ. Paleont. Mineral. Spec. Publ., Tulsa, USA, pp 167-181

Ziegler PA, Schumacher ME, Dèzes P, van Wees J-D, Cloetingh S (2004) Post-Variscan evolution of the lithosphere in the Rhine Graben area: constraints from subsidence modelling. In: Wilson M, Neumann E-R, Davies GR, Timmerman MJ, Heeremans M, Larsen BT (eds) Permo-carboniferous magmatism and rifting in Europe, vol 223. Geological Society Spec. Publ., London, pp 289-317 